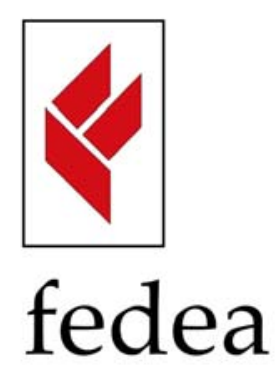

Fundación de

Estudios de

Economía Aplicada

\title{
Are Women Pawns in the Political Game? Evidence from Elections to the Spanish Senate ${ }^{*}$ by Berta Esteve-Volart ${ }^{* *}$ Manuel Bagues ${ }^{* * *}$ DOCUMENTO DE TRABAJO 2009-30
}

\author{
Serie Capital Humano y Empleo \\ CÁTEDRA Fedea - Santander \\ Serie Talento, Esfuerzo y Movilidad Social \\ CÁTEDRA Fedea - Banco Sabadell
}

July 2010
* We are grateful for the useful com ments and suggestions provided by Manuel Arellano, Sam Bucovetsky, Lola Collado, Lena Edlund, Nely Fernández, Stefano Gagliarducci, Maia Güell, Ignacio Ortuño-Ortin, Torsten Persson, Matthew Turner, Celia Valiente, Tània Verge, Natalia Zinovyeva and participants in presentations at FEDEA, York University, the workshop on 'Mothers, Workers, and Retirees: The evolution of women's roles in the economy over the past 50 years' at Wilfrid Laurier University, the First COSME Workshop at the Bank of Spain, ESPE Sevilla, the Second Workshop in Gender Economics held in Granada, EEA Barcelona, EALE Tallinn and the University of British Colum bia. Álvaro Claudio Osuna provided excellent research assistance. Any remaining errors are our own.
** $\quad$ York University.
*** Universidad Carlos III and FEDEA.

Los Documentos de Trabajo se distribuyen gratuitamente a las Universidades e Instituciones de Investigación que lo solicitan. No obstante están disponibles en texto completo a través de Internet: http://www.fedea.es.

These Working Paper are distributed $\mathrm{f}$ ree of charge to Univer sity Department and other Research Centres. They are also available through Internet: http://www.fedea.es.

ISSN:1696-750X 


\title{
Are Women Pawns in the Political Game? Evidence from Elections to the Spanish Senate*
}

\author{
Berta Esteve-Volart ${ }^{\dagger}$ \\ York University
}

\author{
Manuel Bagues ${ }^{\ddagger}$ \\ Universidad Carlos III and FEDEA
}

July 2010

\begin{abstract}
This paper investigates why gender quotas in candidate lists have often lead to disappointing increases in the number of elected female politicians. Using data from Spain, we find that parties tend to nominate female candidates to poorer positions on the ballot, with the exception of constituencies where order on the ballot is irrelevant for the electoral outcome. Taking advantage of the particular framework of Senate elections, where ballot order is alphabetical, we find that these gender patterns reflect parties' strategies: women (but not men) are selected by parties on the basis of last name. We examine whether this is due to voter bias or party bias, and find two pieces of evidence supporting the latter: female candidates attract more votes, and political competition increases female representation.
\end{abstract}

Keywords: strategic nomination, gender, votes

JEL Classification: J16, J71.

${ }^{*}$ We are grateful for the useful comments and suggestions provided by Manuel Arellano, Benito Arruñada, Lori Beaman, Sam Bucovetsky, Antonio Cabrales, Lola Collado, David Dorn, Lena Edlund, Nely Fernández, Raquel Fernandez, Nicole Fortin, Stefano Gagliarducci, Maia Güell, Laura Hospido, Nic Morgan, Ignacio Ortuño-Ortin, Sara de la Rica, Torsten Persson, Matthew Turner, Celia Valiente, Ernesto Villanueva, Tània Verge, Natalia Zinovyeva and participants in presentations at FEDEA, York University, the workshop on 'Mothers, Workers, and Retirees: The evolution of women's roles in the economy over the past 50 years' at Wilfrid Laurier University, the First COSME Workshop at the Bank of Spain, ESPE Sevilla, the Second Workshop in Gender Economics held in Granada, EEA Barcelona, EALE Tallinn, the University of British Columbia, SAE Valencia, CEMFI, Universitat d'Alacant, and Universitat Pompeu Fabra. We also thank two anonymous referees and the coeditor of this journal for many detailed comments that improved the paper greatly. Álvaro Claudio Osuna provided excellent research assistance. Any remaining errors are our own.

†berta@econ.yorku.ca. York University, Department of Economics, 4700 Keele Street, Toronto M3J 1P3, Ontario, Canada.

${ }^{\ddagger}$ mfbagues@emp.uc3m.es. Universidad Carlos III, Departamento de Economía de la Empresa, Calle Madrid 126, 28903 Getafe, Madrid, Spain. 


\section{Introduction}

Given the low participation of women in legislatures worldwide, it is not surprising that political parties and governments in many countries have introduced gender quotas in candidate lists (European Commission 2009). However, this has not resulted in equal numbers of female and male legislators. In 2008, there were only four countries with at least $40 \%$ of female parliamentarians. ${ }^{1}$ According to UNICEF (2007), in 2007, a woman headed the government in only seven countries. Given recent empirical evidence that the gender of legislators matters for policy choices, economists need to pay attention to the sources of this inequality. ${ }^{2}$

It has been argued that the lack of female legislators may reflect voters' preferences for male politicians (Frechette et al. 2008). Other authors point out that it may not necessarily be due to lower popularity among voters, but rather to a political failure (Persico 2009). According to this view, political parties constitute filters between voters' preferences and the politicians who get finally elected. ${ }^{3}$ To the extent that candidates are not selected through an open process, but are rather chosen by political party leaders, such filters may favor incumbents. Given that party leaders are generally male, this might be particularly important for female candidates. On the one hand, parties may be nominating few female candidates relative to voters' preferences, or they may be nominating female candidates to constituencies or ballot positions with no chances of success. This would lead to few women legislators. On the other hand, party leaders might prefer weak (female) colleagues in order to avoid potential internal competition, or they may be nominating female candidates regardless of their quality, just to highlight their 'good' gender statistics. ${ }^{4}$

Spain is currently one of the most advanced countries in terms of gender equality policy. In 1988, the Socialist Party introduced internal gender quotas at $25 \%$ of nomination. The quota was increased to $40 \%$ in 1997. In 2004, their main opponents, the People's Party, also set the goal of progressing toward gender equality in party positions and institutional representation (Verge 2009). ${ }^{5}$ In the same vein, parties have adopted guidelines to nominate more female candidates as heads of candidate lists. ${ }^{6}$ Legislative quotas were put in place in 2007: the Equality Law requires political parties to choose

\footnotetext{
${ }^{1}$ These countries were Rwanda, Sweden, Cuba, and Finland. Source: "Women in Parliaments: World Classification", Inter-Parliamentary Union (http://www.ipu.org/wmn-e/classif.htm, retrieved January 26, 2009), compiling information provided by National Parliaments by November 30, 2008.

${ }^{2}$ Chattopadhyay and Duflo (2004), using data from India's political reservation, and Rehavi (2007), using data from US state legislators, both find that women legislators make different choices regarding public spending.

${ }^{3}$ In Spain, a recent poll by the Centro de Investigaciones Sociológicas finds that $87 \%$ of citizens either agree or strongly agree with the statement that the participation of women in institutions should be encouraged. Encuesta 2588, "Representación y Participación Política en España", 2005, Centro de Investigaciones Sociológicas.

${ }^{4}$ Likewise, if parties do not nominate female candidates to relevant roles, women who may be willing to run for election may not be the best available. Additionally, female candidates might not be chosen based on their quality as politicians. According to some media, Italy's current Prime Minister, Silvio Berlusconi, tends to nominate beautiful female candidates to top legislative positions ("Diverging paths on gender equality", BBC News, May 12, 2008).

${ }^{5}$ Norway led the way to voluntary party quotas: in 1975, both the Socialist Left and the Liberal Party adopted gender quotas; in 1983 the Labor Party, Norway's biggest party, adopted quotas for half of their candidates to be women. This was seen as a legitimate way to ensure that women would receive adequate representation (Matland 2005).

${ }^{6}$ For instance, in the 2004 election the secretary of the Socialist Party in Castilla y León acknowledged that "the majority of the lists for the House and the Senate prepared by local party committees did not satisfy the recommendation of the party's central committee according to which they should place female candidates at the top of the ballot" ("Villalba reconoce que hay pocas mujeres encabezando las listas", Diario de León, January 10, 2004.

Parties receive positive or negative media treatment according to how many women are placed at the top of the list. See, for instance, "Las paradojas de la paridad electoral en Canarias", El Día, February 21, 2008.
} 
roughly equal numbers of men and women for candidate lists. Despite recent increases in the number of women elected, the percentage of women in the House of Representatives and the Senate remains relatively low, at $36.3 \%$ and $28.2 \%$ respectively (Figure 1 ).

In this paper, we analyze why the increase in women in candidate lists has only had a limited effect on the number of female legislators. We study voting behavior and party nomination strategies using data on legislative elections held in Spain in 1996, 2000, 2004 and 2008. In elections to the House of Representatives, voters can only choose which party to vote for, and parties choose freely how to place candidates on the ballot. The electoral chances of candidates depend on the vote received by the party list, and their position in the list. In Senate elections, voters may vote directly for their preferred candidate. Each party presents three candidates per province, who are listed alphabetically on the ballot. A voter may vote for up to three candidates, and the four most voted candidates in each province are elected. Generally, one of the two main parties wins seats for all three of their candidates, with the fourth seat going to the other party.

Political parties can affect the number of female candidates who get elected in two ways. First, in the absence of gender quotas, parties decide how many women they nominate in each province. We find that parties nominate relatively fewer female candidates in constituencies where, based on previous electoral results, the likelihood of being elected is relatively higher.

Second, parties can affect candidates' chances of being elected through their order in the ballot. In House elections, the ballot order determines who gets elected directly. In Senate elections, given that voters tend to have a preference for candidates placed at the top of the list, parties can affect the distribution of votes among candidates in their party list by nominating candidates based on their surname. In both chambers, we find that male and female candidates are allocated to different places in the ballot depending on party electoral expectations. In House elections, less than $30 \%$ of candidates in expected winning positions are female, but they constitute $46 \%$ of all candidates in expected losing positions. In the Senate, $20 \%$ of candidates in expected winning positions are female, while women constitute $53 \%$ of candidates in expected losing positions. This finding is in stark contrast with parties' explicit guidelines regarding nominating more women at the top of lists. In fact, we find that women tend to head lists only when ballot order is irrelevant for election. Female candidates are placed at the top of the ballot in $7 \%$ of all Senate races where the party expects to win only one seat. The pattern reverses in races where a party expects to win all three seats: $47 \%$ of lists are headed by women.

These nomination patterns explain why the commitment of parties to increase both the number of women among candidates, and the number of women topping lists, has had a limited effect on female representation. To understand the nomination strategies of political parties, we exploit the particular framework of Senate elections, where candidates are listed alphabetically on the ballot. If candidates' surname order is not related to their quality, we can compare candidates' surname order with surname order in the overall Spanish population to test whether certain candidates are chosen on the basis of surname. If male and female candidates were not selected based on their surname, we would expect to find, alphabetically, approximately a third of the candidates from either gender in any given ballot position. 
We find that in races where there is no uncertainty about the outcome of the election, parties strategically nominate female candidates (but not male candidates) according to their surname. The strategic nomination of female candidates is done in two different ways. In races where the party does not expect all of their candidates to be elected, we find that women tend to be drawn from later in the alphabet; thus female candidates are less likely to be elected. In races where the party expects all of their candidates to be elected, and therefore ballot order is irrelevant, women tend to be drawn from earlier in the alphabet. In unsettled races, we find the strategic nomination of female candidates to be much weaker.

The party behavior that we observe could either be due to party bias, or to voter bias against female candidates. Specifically, political parties might be strategically nominating female candidates because of party preferences, or they could be reacting to a potential voter preference for male candidates. In order to disentangle between these two theories, we have examined potential gender differences in voting behavior.

First, we compare the votes received by gender. The gender bias in nominations that we observe cannot be justified in a potentially lower ability of female candidates to attract votes: we find that, as opposed to conventional wisdom (and recent work for other countries, such as Frechette et al. 2008), female candidates tend to attract more votes than male candidates. Second, we study the effect of political competition. Not selecting the best candidates might be more costly in races that are expected to be close, in which case the quality of candidates may be more salient. We find that the absence of political competition reduces the number of female candidates who become senators. In settled races, $20 \%$ fewer women are elected compared to unsettled races.

In sum, the evidence is not consistent with the existence of voter bias against female candidates. In the absence of political competition, parties seem to be using women as pawns - in that they are nominated according to how their presence in the list affects male candidates and gender statistics. Political parties value gender equality but, perhaps in an example of 'old boys networks', they do so only inasmuch as it does not cost a male candidate his seat. Paradoxically, in electoral systems where alphabetical order is in place, the strategic nomination of female candidates may have negative effects in terms of quality, as the pool of female party members from which parties choose candidates is constrained.

The evidence reveals that without adequate incentives, gender quotas may not necessarily lead to more female legislators. As this paper shows, quotas fail to erode the strategic nomination of female candidates. In the absence of a competitive political scenario, the design of the ballot should be such that parties cannot use the order effect to favor particular candidates. We propose to replace the current alphabetical ballot order with a ballot order rotation: multiple versions (three in this case) of a ballot are printed, such that each candidate tops the ballot as often as the others, and thus positional misvoting is neutralized. ${ }^{7}$ Given our results, and because incentives for strategic nomination would be eroded in such a framework, rotating the order of candidates in the party list would deliver more

\footnotetext{
${ }^{7}$ State Supreme Courts in the U.S. have ruled listing candidates alphabetically in a ballot unconstitutional on the grounds that candidates higher on the ballot are known to enjoy a vote advantage. American states now use either randomization only or randomization and rotation of candidates' names on ballots (Alvarez et 2006).
} 
and better female legislators.

The paper is organized as follows. Section 2 describes the related literature. Section 3 offers background information on Senate and House elections in Spain, and Section 4 describes the data. Section 5 outlines our research design and methodology, and Section 6 turns to the empirical analysis. In Section 7 we discuss policy implications. Finally, Section 8 concludes.

\section{Related literature}

Our study can be connected to several strands of papers. There is a large literature analyzing the low incidence of women among legislators, including many that investigate whether female legislators attract fewer votes. ${ }^{8}$ Frechette et al. (2008) finds evidence that, controlling for observable characteristics, female candidates get fewer votes than male candidates. Beaman et al. (2009) evaluate the impact of India's mandated political representation of women in village councils on citizens' attitude toward women leaders and find that voters are biased against female candidates, but this bias diminishes once voters get to know the candidates. Darcy and Schramm (1977) looks at several U.S. House of Representatives elections from the 1970s and find that gender has little or no effect on election outcomes. Kelley and McAllister (1984) find that voters in Australia and Britain are less likely to vote for female candidates.

There is a related literature in political science on the low representation by women in Parliaments, which highlights the responsibilities of parties; in particular of their organizational and ideological barriers. For instance, Caul (1999) examines data from 68 parties in twelve developed countries between 1975 and 1989, and finds that parties with a higher degree of institutionalization and localized nomination, are more likely to nominate women candidates.

Some studies have also examined how political parties try to influence election outcomes by using strategic nomination. Among these, there are a number of papers that investigate strategic nomination by constituency. Frechette et al. (2008) finds that in the 2002 French National Assembly election, female candidates were slightly more likely (albeit not statistically significantly so) to be sent to 'worse' districts. In Frechette et al. (2006), they also consider other potential strategic behaviors by political parties, looking at which parties take male bias in the voter population into account. Such strategic behavior would imply that women would be nominated for sure losers and sure winners, while men would be reserved for tight races. Their results go in that direction, but are not statistically significant at standard levels. In contrast, Murray (2004) qualitatively analyzes the 1997 and 2002 French National Assembly elections and argues that in the 2002 election, whereas women were a minority in safe and swing seats, they were better represented in unwinnable seats. ${ }^{9}$ Parties can also influence the outcome of elections in systems where parties decide the ordering of candidates within

\footnotetext{
${ }^{8}$ It is usually difficult to measure candidate quality. Recent studies analyzing the selection of candidates are Ferraz and Finan (2009), Gagliarducci and Nannicini (2009) and Galasso and Nannicini (2009). A measure of politician quality common to these papers is education.

${ }^{9}$ She defines a 'safe' seat as a seat won in both 1997 and 2002, and a 'swing' seat as a seat that changed hands between elections. Unwinnable seats are defined as seats that are neither safe nor swing (Murray 2004).
} 
the ballot, and voters only choose to which party receives their vote. As highlighted by a recent report by the European Commission (2009), in these cases female candidates are usually positioned in poorer list positions than their male colleagues.

There is also a wide literature that studies how different ballot designs lead to systematic deviations in candidate vote shares. One source of bias is position misvoting - where candidates receive more votes because they are listed in a particular place on the ballot. ${ }^{10}$ Positional (mis)voting may be particularly relevant in a framework of personal voting where candidates are listed on the ballot alphabetically. This electoral system has been used in Australia, Britain, Ireland, Spain, and the U.S. among others. Kelley and McAllister (1984) find evidence of alphabetical voting in Australian elections, while similar results are found for the Irish lower chamber (Robson and Walsh 1974), and for the Spanish Senate (Lijphart and Lopez 1988, Montabes and Ortega 2002). ${ }^{11}$

A number of political scientists have analyzed strategic nomination for Senate elections in Spain. Montabes and Ortega (2002) argue that political parties in Spain select candidates with surnames that place them on the list below the incumbent senator. Moreover, Ortega and Morata (2004) show that in the 2000 general election female candidates were placed lower on the ballot, which made it more difficult for them to be elected. In contrast to the previous literature, we consider how strategic nomination differs according to candidates' chances in the constituency.

\section{Background}

Spain is a parliamentary representative democratic constitutional monarchy as established by the Constitution, passed in 1978. The Monarch is the Head of State and the President of the Government is the head of government in a multi-party system. Central legislative power is vested in the Congress (Cortes Generales), which consist of two chambers, the House of Representatives (Congreso de los Diputados) and the Senate (Senado). The House and Senate serve concurrent terms that run for a maximum of four years. House and Senate elections are held simultaneously.

In Spain, a provincial party committee proposes a slate of candidates for nomination to Senate and House lists. Formally, this list must then be approved by the regional and national central committees.

\subsection{Senate}

The Spanish Senate currently comprises 264 senators, 208 are directly elected in general elections, and 56 are appointed by the 17 Spanish regions.

In general, provinces elect four senators each. Each voter has three votes, and votes for candidates by name (the only instance of personal voting in Spanish national elections). Political parties may

\footnotetext{
${ }^{10}$ Shue and Luttmer (2009) additionally consider another type of misvoting-adjacency misvoting-which occurs whenever candidates receive more votes due to being adjacent to a popular candidate.

${ }^{11}$ Order effects have also been documented in other areas: Einat and Yariv (2006) show that economists whose last name order is relatively early in the alphabet enjoy greater academic success.
} 
nominate as many candidates as there are positions available, but in practice (with a few exceptions) ${ }^{12}$ each party nominates three candidates. Usually, the three candidates receiving the most votes each come from one party, with the fourth the most-voted for candidate coming from the opposing party. ${ }^{13}$

On the ballot for Senate elections, candidates are grouped by political party, and political parties are randomly ordered. Within each party list, in turn, candidates are listed in alphabetical order. In Figure 2 we display a scan of the Senate ballot used in the province of Ávila during the 2008 election, and Figure 3 provides the results for this election. The three candidates for the People's Party (in Spanish, Partido Popular, the main right-wing party) were the three most voted for, each winning a Senate seat. The fourth place candidate headed the list for the Socialist Party (in Spanish, Partido Socialista Obrero Español, the main left-wing party).

It is well-known in policy circles (and has been documented by political scientists) that the first candidate in the ballot tends to be the most voted. ${ }^{14}$ Consider the example of Ramón Rubial, a historic president of the Socialist Party, running for the province of Vizcaya, traditionally a right-wing stronghold. Ramón Rubial was an incumbent senator when in 1984 the voting system was modified: party lists on the ballot were randomized, but candidates for each party were listed alphabetically. In the first election with the new system in 1986, parties did not seem to have paid attention to strategic nomination based on surname. Rubial, listed second for the Socialist Party, lost his seat to newcomer Manuel Fernández, listed alphabetically above him on the ballot. To have maximized Rubial's chances of becoming senator, the party should have chosen two other candidates with surnames after his. This is consistent with the evidence: in subsequent elections, any candidate in the Socialist list running with Rubial had an initial no earlier in the alphabet than "S". The list for the 1989 election reads: 1) Ramón Rubial, 2) Dimas Sañudo, 3) Ángel Templano; the list for the 1993 election is: 1) Ramón Rubial, 2) Tomás Tueros, 3) Víctor Manuel Urrutia; for 1996: 1) Ramón Rubial, 2) Edurne Uriarte, 3) Ricardo Villanueva. Other well-known examples are those of Alberto Ruiz-Gallardón, a People's Party leader, who ran for the 1993 Senate election next to Roberto Soravilla and Rosa Vindel in Madrid, and perhaps more ostensibly, Galician left-wing leader Francisco Vázquez, who ran for A Coruña in 2004, together with Maria Vila and Jorge Yáñez.

\subsection{House of Representatives}

The House is formed by 350 members, elected from each province for a maximum four-year term following proportional representation. Seats are allocated as follows: the provinces of Ceuta and Melilla are given one seat each, and two seats are given to each of the other 50 provinces; the remaining 248 seats are then allocated proportionally according to population.

As opposed to the Senate, where voters can vote directly for the candidates of their choice, in House

\footnotetext{
${ }^{12}$ In the 1977 election, Unión de Centro Democrático nominated more than three candidates in the provinces of Castellón, Granada and Salamanca. In the 2000 election, in 24 out of 47 provinces the Socialist Party and United Left agreed that the former would nominate two candidates and the latter would nominate one candidate.

${ }^{13}$ It is very unusual that two parties get two candidates elected each. During the last four elections, this has only happened in three cases.

${ }^{14}$ Personal conversation with former senator Nely Fernández. For political science literature on this issue, see Lijphart and Lopez (1988) or Montabes and Ortega (2002).
} 
elections voters can only choose which party to vote for. In each constituency, each party proposes a list with as many candidates as seats are available. The party decides the order of their candidates in the ballot. Then the number of votes received by every party decides how many seats the party gets; seats are allocated to candidates by order in the ballot.

\section{Research design and methodology}

Our research question deals with the lack of women legislators. Because political candidates are typically selected by political parties, internal and legal quotas in candidate lists are the most common policy to increase female representation, by increasing the share of female candidates in party lists. Some parties have also had a policy of nominating more women to lead slates of candidates. Nevertheless, these policies have not translated into proportionally greater numbers of female legislators.

It has been argued that this reflects the fact that women are nominated to positions where the probability of getting elected is lower. A number of studies in the literature have analyzed this issue (European Commission 2009). More precisely, the descriptive analysis that lies in the background of the standard literature can be shown with the following regression:

$$
\text { Position }_{i l}=\beta \text { Female }_{i}+X_{i}^{\prime} \gamma+Z_{l}^{\prime} \psi+u_{i l}
$$

where Position $_{i l}$ is a variable measuring the position of candidate $i$ in party list $l$ that she is running

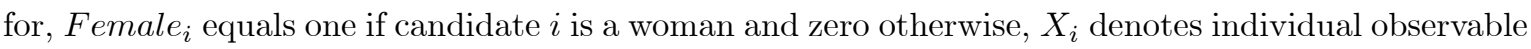
characteristics of candidate $i$, and $Z_{l}$ denotes observable characteristics of party list $l$.

In order to explore the origin of these gender patterns, in this paper we exploit a particular feature of the Spanish political system in order to distinguish between the three hypotheses: the alphabetical order of candidates in Senate elections party lists. Because voters tend to have a preference for candidates placed at the top of the list, having a surname late in the alphabet might be a drawback. Similarly, a candidate whose surname initial is early in the alphabet is relatively more likely to head the party list, which might give them an advantage over the other candidates in the same party list.

Here, we examine the surname order of male and female candidates, and we then compare it with the distribution of surnames in the Spanish population at large. We examine whether female candidates are strategically nominated by parties to be placed in certain positions in the list:

$$
\text { Surname order }_{i}=\beta \text { Female }_{i}+X_{i}^{\prime} \gamma+u_{i}
$$

where Surname order $_{i}$ is a measure of the alphabetical order of candidate $i$ 's surname.

Our identification strategy relies on the fact that potential candidates' surname order is not directly related to quality (an issue that we will get back to in the empirical analysis), yet it affects candidates' electoral chances. This allows us to identify whether a certain group of candidates (here, women) has

been selected on the basis of surname, not quality. For example, if we observe that female candidates 
tend to have surnames from the end of the alphabet relative to the population, this would suggest that female candidates were selected with regard to their surname.

As candidate quality is hard to observe, the typical study in the literature cannot ascertain whether women are nominated to poorer positions because (1) parties are biased against female candidates, (2) voters are biased against female candidates; leading parties to place female candidates in poorer list positions. In order to disentangle between these two possibilities, we test whether female candidates are less popular among voters, holding everything else constant, by running regressions of the form:

$$
\text { Votes }_{i l}=\alpha_{l}+\beta \text { Female }_{i l}+X_{i l}^{\prime} \theta+\gamma \text { Position }_{i l}+v_{i l}
$$

where $V_{\text {otes }}$ il is the share of votes of candidate $i$ running for party list $l$, and $\alpha_{l}$ is a list fixed-effect.

If the strategic nomination of female candidates is driven by party bias, we would expect this to be more salient in constituencies where political competition is low. We examine the relationship between political competition and female representation with the following regression:

$$
\text { Female Senator } s_{c t}=\alpha_{c}+\varphi \text { Unsettled }_{c t}+X_{c t}^{\prime} \lambda+\varepsilon_{c t}
$$

where Female Senator $s_{c t}$ is the number of senators elected in constituency $c$ in election year $t, \alpha_{c}$ is a constituency fixed-effect, Unsettled $_{c t}$ is a dummy variable that takes value one for races in which there there was uncertainty about the electoral outcome, and $X_{c t}$ is a vector of controls.

\section{Data}

We use information on candidates in Spanish legislative elections held since 1996. Our database includes data from all of the peninsular provinces where political competition is between the two main parties (43 of 47 provinces, see the Data appendix for details). Therefore our database includes a total of 312 party lists to Senate and House elections. We have gathered information on candidates' name and surname, political experience, and electoral performance. For robustness checks, we have collected information on the senators appointed by the regions, as well as on all of the candidates to Spanish local elections in 2008.

Using information on the first name and surnames of candidates, we are able to calculate their gender and surname order. In Spain, it is almost always possible to tell a person's gender by their first name, so we have information on the gender of candidates. In the few cases in which gender was not clear, we verified this information by checking pictures of the candidates.

The Spanish use two surnames: the first is inherited from the father's paternal lineage, and the second from the mother's paternal lineage. We use the distribution of surnames in the Spanish population by province to create a measure that orders surnames alphabetically, and we call it surname order (for details on the calculations, see the Data appendix).

In Table 1 we report statistics for the surname order of the individuals analyzed in this paper. As 
can be seen in the table, female Senate candidates' paternal surnames tend to be closer to the end of the alphabet than male candidates' surnames. We do not observe any significant gender difference in Senate candidates' maternal surname order. The same is true for any of the other groups of politicians we consider: elected senators, appointed senators, House candidates, elected House members, candidates to local elections, or mayors.

In Table 2 we display information on Senate candidates' political experience and electoral performance by gender. Male candidates tend to have relatively more relevant political experience: they are more likely to be former senators or former House representatives. Male candidates are more likely to be placed at the top of the ballot, and tend to obtain a slightly larger number of votes.

\section{Empirical analysis}

In this section, we first analyze how parties nominate candidates by gender; taking into account, for every position, their probability of getting elected. Second, given that order in the ballot in the Senate is alphabetical, we check whether parties nominate candidates on the basis of surname. Third, we use voting information to investigate parties' behavior.

\subsection{Nomination}

In this section, we analyze why the increase in women in candidate lists has only had a limited effect on the number of female senators. Next we consider whether parties' nomination strategies for both chambers might explain this puzzle. ${ }^{15}$

\subsubsection{House of Representatives}

Party lists in elections to the Spanish House of Representatives are closed: voters can only choose which party to vote for. In addition, every party chooses freely how to position their candidates in the ballot. The electoral chances of candidates depend on the votes received by the party in the constituency to which they are nominated, and their position in the list.

We classify positions in House lists according to how predictable the outcome of the election is given the results in the previous election. In particular, if the party had obtained X House seats in the previous election, we consider expected winning positions the X-1 first positions in the list. In our sample, in $99 \%$ of the cases, candidates in expected winning positions did get elected. Analogously, we consider unsettled positions the $\mathrm{X}$ and $\mathrm{X}+1$ positions in the list. A candidate running in an unsettled position has a probability of getting elected of 50\%. The remaining positions constitute expected losing positions. Only $1 \%$ of candidates in expected losing positions in our data base got elected.

\footnotetext{
${ }^{15}$ In what follows we only report results from aggregating all parties. Performing the analysis by party yields very similar results.
} 
Figure 4 shows the proportion of female House candidates by type of position: women tend to be nominated to poorer positions. In expected winning positions, almost $30 \%$ of candidates are female. This figure is $41 \%$ for unsettled positions, and $46 \%$ for expected losing positions respectively. This finding is in stark contrast with parties' explicit guidelines regarding nominating more women at the top of lists. We then examine the presence of women as head of House lists. According to our calculations, women are less likely to head a list when the party expects to win only one or two seats, compared to cases where the party expects to win three or more seats ( $14 \%$ vs. $25 \%$ respectively).

\subsubsection{Senate}

As explained in detail in Section 3, each political party nominates three candidates to the Senate in each province, and four senators are elected per province. Typically, three of the four elected senators are from one of the two parties.

In this section we classify positions according to candidates' electoral chances. We consider two dimensions: first, we study whether it is possible to predict how many seats will be obtained by each party based on previous electoral results; second, within each list, we examine whether it is possible to forecast which candidate obtains more votes.

Figure 5 shows the relationship between (a) the vote advantage obtained by the leading party in the previous election, and (b) the share of cases where the leading party in the previous election wins three seats in the current election. As expected, the frequency with which parties obtain three seats is greater the higher their vote advantage in the previous election. Whenever the difference in votes between the two parties was lower than $15 \%$ in the previous election, the same party obtained three senators in the following election in about $50 \%$ of cases. This figure rises up to $76 \%$ in the case that the difference in votes was between $15 \%$ and $30 \%$, and up to $86 \%$ if we consider races where the vote difference was between 30 and $45 \%$. Finally, whenever a party had received $45 \%$ more votes than its competitor in the previous election, the party obtained three seats in the following election.

We distinguish between "settled" and "unsettled" races. We define "settled" races as those where one party obtained $45 \%$ more votes than the other in the previous election. We classify any race where the vote difference in the previous election was lower than $45 \%$ as "unsettled". Based on this, we can distinguish three types of lists. Within settled races, the party that expects to elect all three candidates has an expected winning list, and the party that expects to elect only one candidate has an expected losing list. For unsettled races, all party lists are unsettled lists.

In Figure 6 we show maps with party lists classified according to this taxonomy. Each map represents one election. The figures show how, in different provinces, and based on previous electoral results, either the election is settled in favor of one party, or the outcome is uncertain. The lighter color represents provinces where the left-wing was expected to win (or, equivalently, the right-wing was expected to get only one seat). This was the case, for instance, of Girona in the 2008 election. The medium color represents unsettled races; an example would be either the Socialist Party or the People's Party in Asturias in any of the elections. The darker color represents right-wing expected winning 
lists (or, equivalently, left-wing expected losing lists). An example is Zaragoza in the 2000 election.

Next we study if it is possible to predict which candidate in a given party list attracts more votes. This is particularly important in expected losing lists, where only one candidate is likely to be elected.

In Senate elections, the electoral chances of every candidate depend on the votes received by that candidate. While theoretically possible for candidates who are not at the top of the list to get more votes, we observe a strong order effect: candidates placed at the top of the list are more likely to get elected. For instance, in the last four Senate elections, heading the list translated into receiving the most votes in a staggering $97 \%$ of cases (Table 3).

In sum, in expected winning lists, parties expect all three candidates to be elected independent of their ballot position. In contrast, in expected losing lists, parties expect to win only one seat. Empirical evidence suggests that the candidate at the top of the ballot list will be elected, whereas candidates in the second and third places will not be elected. In the case of unsettled races, both parties know that the first candidate in their list will be elected, but they are uncertain about their respective second and third candidates.

Now we examine, for each type of lists, whether there are any difference in terms of (a) how many male and female candidates are nominated, and (b) the ballot order of male and female candidates.

Table 4 provides descriptive information on the share of women by order in the ballot and type of list. As shown in the last row of the table, parties nominate relatively more female candidates in races where the likelihood of being elected is relatively lower. We find that an average $26 \%$ of candidates are female in expected winning lists, but for expected losing lists, $38 \%$ of candidates are female. The figure falls in between for unsettled races, $33 \%$ of candidates are female. ${ }^{16}$

In column (1) in Table 5 we regress the share of women in lists by the type of list. Throughout this paper, we cluster standard errors by year and province to take into account the fact that (the votes received by) candidates within the same race may not be independent observations. We find that, as suggested by Table 4, women are significantly less likely to be on expected winning lists than on expected losing lists. It could be argued that women are disproportionately present in expected losing lists because there were more female candidates in the list from the previous election, which they lost. In column (2) we control for the share of women in lists in the previous election and for which party had won. Women are still less likely to be on expected winning lists than on expected losing lists. Therefore, it is not that lists in which there are more women tend to lose; rather, parties nominate relatively fewer (more) women in lists where they expect to obtain relatively better (worse) results.

There also exists a striking contrast in terms of the positions in which male and female candidates are placed across types of lists. In expected losing lists, parties tend to place women in either the second or third places, where they will not get elected (Table 4 ). In fact, only a meager $7 \%$ of candidates heading these lists are female, while $56 \%$ of candidates at the bottom of these lists are female. In expected winning lists, the pattern reverses: women are disproportionately more likely to head lists:

\footnotetext{
${ }^{16}$ The number of female candidates is relatively low in all three cases. This might partially reflect the low numbers of women in political parties. In 2004, the percentage of female affiliates was $30.9 \%$ in the Socialist Party, and $33.6 \%$ in the People's Party (Verge 2006).
} 
$47 \%$ of candidates topping these lists are female; only $12 \%$ of those at the bottom are. Unsettled races are somewhat in between: women tend to be more towards the bottom of the ballot, but much less so than in expected losing lists (women at the top and at the bottom of the list are about $19 \%$ and $42 \%$ of all candidates, respectively). Symmetrically, male candidates exhibit the opposite pattern.

The gender patterns we observe in party nomination strategies could be due to the fact that male candidates tend to be more experienced. Next we study party nomination strategies controlling for prior political experience. We report the results from estimating equation (1) by type of list in Table 6. While more experienced candidates tend to be placed relatively better on the ballot, the pattern in Table 4 still holds true: female candidates are more likely to top the list in expected winning lists, and less likely to top expected losing or unsettled lists, especially in the former.

Our results suggest that women in both House and Senate lists have lower electoral chances because they are nominated to poorer positions. Moreover, women tend to be nominated as head of lists in constituencies where the candidates in other positions in the list will also get elected. Placing women at the top only where it is irrelevant allows parties to satisfy their objective of having at least a few lists headed by women, without sacrificing male party favorites.

Next we explore whether nominations to head Senate lists are connected with nominations to head House lists. Parties may have a preference for having gender parity at the top of the lists, that is, for having, out of the two heads of lists (Senate and House), one woman and one man. If this is correct, we should find a woman at the top of the Senate ballot more often when the House list is headed by a male candidate than when it is headed by a female candidate. The descriptive evidence in Table 7 is consistent with this idea: in expected winning constituencies it is more likely that a woman heads the Senate than the House list ( $47 \%$ vs. $23 \%$ of the cases, respectively), but the opposite is true in expected losing constituencies ( $7 \%$ vs. $30 \%$ ). In Table 8 we formally test the hypothesis. We regress the probability that a woman tops the House list on whether a woman tops the Senate ballot. In column (1) we present cross-sectional evidence consistent with a negative correlation; in column (2) we present fixed-effects evidence. Results suggest that placing a woman at the top of the Senate (House) list is positively associated with having a man leading the House (Senate) list. In sum, there seems to be some level of substitution between women topping Senate and House lists in settled constituencies.

\subsection{Strategic nomination of candidates and surname order}

We have shown that there are gender patterns in the way that candidates are placed in ballots, and that these depend on the party's chance to win the election. In this section, we exploit the particular setup of Senate elections to investigate why female candidates are nominated to certain positions.

Given that order in the Senate ballot is alphabetical, we can investigate if parties are strategically selecting candidates by their surname. This could affect male candidates, female candidates, or both.

If parties are strategically nominating a group of candidates based on surname, the distribution of their surname order will not be a random sample of the populational distribution. Therefore, if 
surname order is not correlated with true quality, by comparing the distribution of surnames for male and female candidates with the populational distribution of surnames we can obtain information about whether these candidates were nominated based on their surname (as opposed to quality). Our identification strategy would be flawed if, for instance, in the Spanish population surname order was associated with income or education. Below, we first show that surname order is not correlated with candidate quality, and then examine if certain candidates are chosen on the basis of surname order.

Figure 7 shows the relationship between surname order (by decile according to alphabetical order) and educational level by gender, measured as the share of individuals with at least an undergraduate degree. On average, approximately $14 \%$ of the population has an undergraduate degree. ${ }^{17}$ While slight differences exist in the share of graduates across deciles, there is no correlation between surname order and the share of male and female graduates. In sum, Census information suggests no clear relationship between surname order and educational attainment across individuals.

Another potential threat to the validity of the identification would exist if individuals could change their surname and, thus, affect ballot order. This is not the case in Spain, where surname changes are extremely restricted and are very rare (Ley de Registro Civil, Article 57). For instance, in 2001, only 1426 surname changes were granted (Anuario de la Dirección General de los Registros y del Notariado, Ministerio de Justicia, 2002). Most of these changes involved hyphenating the paternal and the maternal surname to create a new surname - e.g., Esteve-Volart - and did not affect surname order. Moreover, in Spain, women cannot adopt their husband's surname.

Figure 8 shows the average surname order of Senate candidates by gender and type of list (panel A). Since, by construction, our measure of surname order in the population has a mean equal to 0.5 , any systematic deviation from 0.5 in the distribution of male and female candidates' surnames is consistent with surname based nomination. The evidence rejects the hypothesis that the distribution of female candidates' surnames is the same as that of the Spanish population, particularly in settled races. In fact, their surnames differ according to constituency: in expected winning lists, women tend to be drawn from the beginning of the alphabet ( 0.29 on average). In expected losing lists, women's surnames tend to be drawn from the end of the alphabet ( 0.70 on average). In unsettled races, the distribution of women's surnames is closer to the population distribution, but the average surname order is still statistically higher than 0.50 ( 0.55 on average). In other words, while in expected winning lists on average the surname of female candidates is "Fernández", in expected losing lists the average surname is "Pardo". ${ }^{18}$ In contrast, in all three cases, the distribution of male candidates' surnames does not differ significantly from the distribution of surnames in the Spanish population.

The bottom line from the panel A in Figure 8 is that female candidates are selected on grounds of surname, but male candidates are not. In expected winning lists, women with surnames early in the alphabet are more likely to be nominated. In expected losing lists, and to a certain extent, in unsettled races, women with surnames late in the alphabet are more likely to be selected.

\footnotetext{
${ }^{17}$ The data come from the Census of Santander 2001 and involves individuals between 30 and 70 years of age. We thank Lola Collado and Ignacio Ortuño-Ortin for providing us with the data.

${ }^{18}$ We have also performed the calculations using the national distribution of last names instead of the distribution by province. The correlation between both measures is above $99.9 \%$ and all results are identical.
} 
In Table 9 we run regression (2) to investigate whether this pattern reflects gender-based selection or if it is due to female candidates being different in some respect-for instance, women are less experienced. In columns (1), (3) and (5) we run regression (2) by type of list including party and year dummies. In expected winning lists, female candidates are significantly more likely to have a surname closer to A. In expected losing lists, female candidates are significantly more likely to have a surname closer to Z; in unsettled races this is also the case, but the association is weaker. In columns (2), (4) and (6) we also control for political experience. Incumbents tend to have surnames earlier in the alphabet in unsettled and expected losing lists. While the statistical significance is lower, we still find that surname order is associated with gender, depending on the type of list.

Our empirical analysis reveals that when the Senate election outcome is known beforehand, parties strategically nominate female candidates (but not male candidates) according to their surname. This strategic nomination is done in two ways. Where only one candidate will be elected, we find that parties nominate women with surnames later in the alphabet; thus female candidates are less likely to get elected. Where all candidates in a party list are expected to be elected, and therefore ballot order is irrelevant, parties nominate women with surnames earlier in the alphabet.

\subsubsection{Robustness checks}

One concern with the above findings is that surname order might be correlated with unobserved quality. Next we would like to perform a number of robustness checks, to make sure that our findings are not reflecting that possibility. We show the results in panels B through D in Figure 8.

In panel B, we use the surname order of candidates' maternal surnames. Here, the idea is that, if there is strategic nomination by parties, only the paternal surname should play a role. If we still find differences in the nomination of candidates by gender and maternal surname order, then there must be something else at play in panel A-perhaps something related to particular political dynasties and gender. As we expected, though, the results show that we cannot reject that the mean of candidates' maternal surnames (both male and female) is different than 0.5 .

In panels $\mathrm{C}$ and $\mathrm{D}$ we use data from local elections, where most candidates to legislative elections started their political career. The robustness check relies on another possible link between surname order and quality: this could exist if individuals with a given surname order invest more in a political career. In this regard, we should note that alphabetical voting is only in place in Spain for Senate elections. In all other sorts of elections (local, regional, House of Representatives), surname order does not play a role. In panel $\mathrm{C}$ we use data on all of the mayors in Spain, and in panel $\mathrm{D}$ we use data on all candidates to local elections. As expected, in neither of the two panels can we reject that the mean surname order of politicians is different than the populational mean.

Finally, it might be argued that the threshold used to classify races as settled or unsettled is somewhat arbitrary. In order to test the robustness of our results, we have also performed our analysis using a difference of $30 \%, 40 \%$ and $50 \%$ as the threshold. Results are qualitatively similar. 


\subsection{Why do parties strategically nominate female candidates?}

Our results show that parties tend to nominate female candidates with surnames such that they are positioned in either the second or third positions in the list, where their chances of election are lower. Only in constituencies where the party expects all candidates in the list to get elected, do we see that female candidate names are from early in the alphabet and thus head lists. Why are political parties nominating female candidates in this fashion?

This could be due to either party bias, or voter bias against female candidates: if male candidates are more popular among party supporters, this could explain parties' behavior. Political parties might be strategically nominating female candidates because of party preferences, or they could be reacting to a potential voter preference for male candidates. ${ }^{19}$ We test between these two hypotheses with two testable implications. First, we compare the votes received by gender. Second, we compare races with higher and lower levels of political competition.

\subsubsection{Votes}

In this section we turn to voting data in order to test whether female candidates are less popular among voters. We estimate regression (3) using the share of votes of candidates as dependent variable and a female dummy and list fixed-effects as explanatory variables. A list is defined over a given year, for a given province, and for a given political party (e.g., Madrid Socialist Party 1996). List fixed-effects capture any omitted variables that might be affecting the votes received by all individuals running in a given list.

We present the results in Table 10. Male and female candidates in the same party list obtain a similar number of votes (column (1)). Controlling for ballot order, women significantly attract 0.16 percentage points more votes (column (2)). Even though the vote premium associated with female candidates is statistically significant, its magnitude is relatively small compared to the effect of the order advantage, and it rarely manages to overcome it. ${ }^{20}$ Being at the top of the list is associated with an increase of 1.7 percentage points in votes with respect to the candidate positioned at the bottom of the ballot. This is in line with previous literature. For example, Miller and Krosnick (1998), using data from the 1992 U.S. general election in Ohio find that candidates listed first obtain on average 2.5 percentage points more votes; Koppell and Steen (2004) find an effect of 1.6-2.3 percentage points using data from the 1998 Democratic primary election in New York City. In those elections, the order effect was generally not large enough to decide the outcome. In contrast, the design of the Spanish Senate elections makes the order effect decisive in almost every case.

\footnotetext{
${ }^{19}$ An alternative supply side explanation is also feasible but does not seem plausible. Our results could potentially arise due to candidates' self-selection: it is theoretically possible that it is female candidates whose last name is towards Z (A) who are offering/accepting to run for expected losing (winning) lists. However, there is no reason to think that, in losing lists, only women whose last name would place them at the bottom of the ballot (where they will not get elected) would want to become candidates. It would be even more difficult to understand why the opposite might happen in winning lists (where all party candidates will get elected).

${ }^{20}$ In the 2008 election, only in one case did the candidate at the top of the ballot receive fewer votes than the second candidate. In Salamanca, the (female) candidate listed second, Josefa Mena, obtained more votes than the head of the list, Emilio Melero, the (male) local Socialist Party leader.
} 
Due to the late incorporation of Spanish women in politics, there is a wide disparity in the political experience of male and female candidates. In column (3) we present results from adding prior political experience. Candidates with relevant political experience tend to obtain a greater share of votes. At the same time, we observe a slight increase in the number of votes that women attract. Results are qualitatively similar across types of lists (columns (4)-(12)).

Table 11 shows the results from running regression (3) by year, controlling for ballot order and prior political experience. While in 1996 there was a small, insignificant male premium (column (2)), since 2000 we observe an increasing female premium that by 2008 has become significantly positive at the $5 \%$ level (second panel, columns (3) through (5)).

The bottom line from this analysis is that the fact that female candidates in losing lists are placed towards the end of the ballot cannot be explained by male candidates' greater popularity among voters. Note that our analysis is not accounting for the potential negative selection that arises due to parties' strategic selection of female candidates based on surname. Our estimates should thus be interpreted as a lower bound of the true effect.

\subsubsection{Political competition}

In Table 12 we report results from running regression (4), testing whether the number of female senators is lower in constituencies with lower political competition. The share of female elected senators is 6 percentage points (around 20\%) significantly higher when there is uncertainty about the outcome of the race (column (1)). This result is robust to the inclusion of provincial fixed-effects (column (2)), suggesting that this correlation is not driven by some unobserved factor that makes certain provinces more prone to political competition and more female friendly at the same time.

\subsection{Where are the missing female candidates?}

What happened to potential female candidates in constituencies where the party is expected to win, but whose surname is "too late" in the alphabet? In constituencies where parties expect to obtain only one seat, what happened to potential female candidates with surnames "too early" in the alphabet? We consider three possibilities: that these women are directly appointed to the Senate, that they are nominated to the House of Representatives, or that they are not nominated at all. ${ }^{21}$

\subsubsection{Appointed senators}

As explained in Section 3, senators are either elected by voters or directly appointed by the regional Parliaments. For example, in 2008, out of 264 senators, 208 were elected and 56 were appointed. It is

\footnotetext{
${ }^{21}$ It is also possible that there is a relatively small pool of potential female candidates, and parties are nominating female candidates to run for provinces from which they are not from. We have checked the lists and have verified that every female candidate running in expected winning lists was either born in the province, or a province resident.
} 
possible that female party members with surnames that make them "inappropriate" for inclusion in their party's Senate lists end up directly appointed as senators. Here we test this hypothesis.

In the period we consider, only 27 appointed senators are female (19\% of a total of 142 ). This is relatively few compared to the 206 female elected senators (25\% of a total of 832 ), suggesting that parties have in general not accommodated the excluded female party members with seat appointments to the Senate. If anything, parties might have taken advantage of the fact that appointed seats are not subject to party and legislative quotas to appoint male party members.

In columns (1)-(3) in Table 13 we run regression (2) by type of list on appointed senators. In general, we find no significant gender patterns, except for the fact that female appointed senators are marginally more likely to have a surname early in the alphabet.

\subsubsection{Candidates to the House of Representatives}

Elections to the House and to the Senate are held simultaneously. It is possible that female party members with "inappropriate" surnames for the Senate list are allocated to House lists. For instance, consider a female party leader located in a constituency where her party is expected to obtain only one Senate seat. If her surname is early in the alphabet, including her in the Senate list will mean other Senate candidates from her party will not be elected. If the party wishes to nominate her, but prefers another candidate for the Senate seat, they might include her in the House ballot, where lists are closed and ballot order is determined by the party. In other words, the female candidates missing from Senate lists might be running for House seats.

In columns (4)-(6) in Table 13 we run regression (2) by type of Senate list using the sample of candidates to the House. We do not observe any significant gender pattern in surnames in constituencies where the party expects to get three Senate seats (column (4)) or in unsettled constituencies (column (5)). In constituencies where the party expects one Senate seat, female House candidates are more likely to have surnames early in the alphabet; this effect is significant only at the $10 \%$ level. Given that surname order plays no role in House lists, this is consistent with parties' nomination strategies in the Senate having an influence on the nominations to the House.

\subsubsection{All candidates}

The strategic selection of female candidates in the House and in the Senate in settled constituencies goes in opposite directions. To study the net effect, in columns (7)-(9) of Table 13 we examine the nomination of all candidates to legislative elections, together with appointed senators. Overall, women's surnames tend to be significantly earlier in the alphabet in expected winning constituencies (column (7)) and significantly later in the alphabet in unsettled constituencies (column (8)). Women in expected losing constituencies have surnames late in the alphabet, but this is not significant (column (9)). In sum, parties' nomination strategies in the Senate have a net effect on the overall pool of female candidates to legislative elections. 


\subsection{Discussion: gender quotas}

Our evidence suggests that parties nominate women strategically to certain positions in lists. Here we examine how the strategic nomination may have changed with mandatory gender quotas.

In addition to party voluntary gender quotas, legislative quotas were introduced in Spain via the Equality Law in 2007, mandating at least a third of each gender in every Senate list, as well as at least $40 \%$ of women in every House list. In aggregate, the Equality Law has led to an increase in the share of female Senate candidates from $30 \%$ in 2004, up to $38 \%$ in 2008. As shown in Figure 9, this increase has been driven by expected winning lists, where the share of female candidates was lower than the one-third threshold imposed by the law. Nevertheless, and as shown in Figure 10, we observe that in unsettled races political parties still select female candidates based on their surname order.

In the case of the House, while the share of female candidates has increased since the Law was passed (from $41 \%$ in 2004 to $46 \%$ in 2008), the number of female House members has remained at $36 \%$. This reflects the fact that the share of well placed female candidates has remained low (Figure 11). Hence, while quotas have a direct impact on the number of female candidates, they do not affect party nomination strategies, thus have a limited effect on the number of women elected. ${ }^{22}$

\section{Conclusions}

Many countries have committed to greater numbers of women in candidate lists to increase the number of women legislators. The success of these policies has been limited, presumably because women tend to be nominated to poorer positions in the list. This paper examines party nomination strategies for Spanish legislative elections to shed light on the low female representation.

We find that parties nominate female candidates to the bottom of candidate lists in both Senate and House elections, where they have lower chances of getting elected. Additionally, we find that political parties adhere to their guidelines regarding more women heading lists, but only in constituencies where ballot order is not relevant for the electoral outcome.

The particular framework of Senate elections allows us to study whether these nomination patterns reflect party strategies regarding the gender of candidates. In these elections, voters choose among candidates ordered alphabetically in the party list; typically favoring the candidate at the top of the list. This opens the possibility for parties to pick candidates on the basis of surname. Our evidence shows that, especially in constituencies where political competition is absent, parties strategically select female candidates by surname, according to how their presence and position in the list affects male candidates and gender statistics.

The strategic selection of female candidates takes two ways. In expected winning lists, where all candidates will become senators and thus ballot order is not relevant for election, parties nominate

\footnotetext{
${ }^{22} \mathrm{~A}$ system of seat reservation is in place in India, where only women can run for a third of the seats in certain elections. Such system would ensure a given number of female legislators automatically.
} 
women whose surname positions them at the top of the ballot, possibly to embellish their gender statistics. In expected losing lists, where typically only the candidate at the top of the ballot gets elected, parties select female candidates with surnames which position them toward the bottom of the ballot. Additionally, we find that parties nominate fewer women in constituencies where they expect to win relatively more seats. Despite surname order not playing any role in House elections, a number of female House candidates are also selected based on their surname, and this is connected to party expectations in Senate elections.

We rule out that our results reflect a potential correlation between surname order and unobserved politician quality using information from a number of additional sources. First, Census information does not show any clear relationship between the surname order of the Spanish population and their educational level. Second, we use information from local elections, where most candidates to legislative elections started their political career. We find that the surname order of mayors is not significantly different from that of the overall population; the same is true if we use the sample of all candidates to local elections.

Our evidence suggests that the gender bias in nominations cannot be justified by a potentially lower ability of female candidates to attract votes: against conventional wisdom and recent work for other countries, we find that in Spanish elections, female candidates attract more votes. Consistent with the existence of party biases, the degree of political competition plays an important role in the selection of female candidates: in unsettled races, where there is uncertainty regarding the number of seats each party will win, we find strategic nomination of female candidates to be much weaker. We also find that the number of female candidates elected is higher in these races. The fact that strategic nomination is stronger in the absence of political competition is consistent with Becker (1957)-political parties focus relatively more on candidate quality when it is more costly not to do so.

There are at least two stories that are consistent with our results. Political parties do value the presence of women in lists, and they value placing female candidates at the top of the ballot but, in an example of 'old boys networks', parties adopt gender parity whenever it is not costly for male candidates. Alternatively, male candidates may be better than female candidates in dimensions that are unobservable to voters but are observable to party leaders.

The results in this paper suggest that gender quotas have a limited effect on female representation. In the absence of political competition, the ballot design allows parties to place female candidates on the ballot strategically. For this reason, the gender quotas in candidate lists, as well as the parties' commitment to place women at the top of the list, have a limited effect in terms of gender parity. Paradoxically, in electoral systems where alphabetical order is in place, the strategic nomination of female candidates may have negative effects in terms of quality, as the pool of female party members from which parties choose candidates is constrained.

An increase in the degree of contestability of electoral races would enhance the quality and quantity of female senators. Unfortunately, the degree of political competition is seldom a policy option. Alternatively, an effective implementation of quotas requires a ballot design that prevents parties 
from exploiting the order effect to favor certain candidates. ${ }^{23}$ In order to eliminate the existing order effect, we propose ballot order rotation: ballot positions are rotated across candidates, and multiple versions printed, so that every candidate tops the ballot as often as every other candidate. ${ }^{24}$ In terms of costs, since in Senate elections parties only nominate three candidates per list, rotation ordering would in practice imply printing only three versions of a ballot. Rotation would neutralize the existing order effect and erode surname based nomination. Given the results in this paper, rotation would increase the effectiveness of gender quotas.

\section{Data appendix}

In this paper we use data from elections to the Spanish Senate held during the years 1996, 2000, 2004 and 2008. We have restricted our sample in several ways. First, for simplicity we exclude constituencies where fewer than four senators are elected. That is, we restrict the analysis to peninsular provinces (47 as opposed to 50 provinces). The insular provinces (Balearic and Canary Islands) elect one, two or three senators per island, and Ceuta and Melilla elect two senators each. In constituencies electing fewer than four senators, voters correspondingly have fewer than three votes. Second, we exclude two provinces from our analysis where, historically, the political competition in Senate elections has involved more than two political parties (three parties have obtained representation in the Senate in one of the last four elections in Vizcaya and Guipúzcoa: the Socialist Party, the People's Party, and the Basque Nationalist Party). The reason for doing so is that the nomination incentives of parties may vary greatly depending on the number of potential competing parties they are facing. Third, we consider only the two main parties in each province, in practice the only two parties that can expect to get seats. The two main parties are the Socialist Party in all provinces, and, except for the Catalan provinces, the People's Party. In Catalan provinces, the CiU (Convergència i Unió, Catalan nationalists) competes against the Socialist Party. For Senate elections, in Navarra the People's Party ran in a coalition with Unión del Pueblo Navarro during the period considered, while in Catalonia since 2000 the Socialist Party runs in a coalition with Iniciativa per Catalunya and Esquerra Republicana de Catalunya. Fourth, in order to restrict our analysis to lists of three candidates we exclude 24 provinces where, in 2000, the Socialist Party nominated only two candidates as the result of an agreement with the left-wing coalition United Left (Izquierda Unida), which in turn nominated only one candidate. Therefore our database includes a total of 312 party lists. Since each political party nominates three candidates per list, this makes a total of 936 candidacies. Information on candidates' names and the number of votes obtained was available at the website of the Ministry of the Interior. ${ }^{25}$

We have obtained information about the distribution of surnames in the Spanish population from the

\footnotetext{
${ }^{23}$ Senate ballot reform is currently being discussed and a Senate committee has been formed to deliver recommendations. Among other changes, the committee argues for letting parties set the order in the ballot ("La papeleta para elegir el Senado será más pequeña, sencilla y ordenada", El Mundo, June 16, 2009). The advantage would be to erode the current incentives for surname selection of female candidates. However, the proposed system will not eliminate the order effect, it will just make it less costly for parties to exploit the order effect to favor certain candidates.

${ }^{24}$ The system is called Robson rotation, after Neil Robson, the Liberal member of the House of Assembly who introduced it in Tasmanian elections in 1979 (Tasmanian Parliamentary Library, http://www.parliament.tas.gov.au/tpl/Backg/HAElections.htm, retrieved June 9, 2009). A rotating ballot is presently used in some elections in Australia, as well as in the United States (King and Leigh 2009, Alvarez et al 2006).

${ }^{25}$ http://www.elecciones.mir.es, retrieved April 1, 2009.
} 
Census 2007. It was compiled by the Spanish Bureau of Statistics (Instituto Nacional de Estadística).

We use the distribution of surnames in the Spanish population by province to create a measure that orders surnames alphabetically, and we call it surname order. We do this for individuals' paternal and maternal surnames separately. We have normalized this variable to take values between zero and one. When many people share the same surname, we calculate the surname order assuming that the individual is placed at the middle of all individuals bearing that surname. For instance, an individual living in Madrid whose surname is Ruiz-Gallardón receives a value of 0.8486 . In other words, $84.86 \%$ of the population in Madrid has a surname alphabetically before the surname Ruiz-Gallardón, and $15.24 \%$ of the Spanish population has a surname alphabetically after Ruiz-Gallardón.

We have also collected information on the surname order of candidates to the House of Representatives, and on their position on the ballot by gender. ${ }^{26}$ In the period we consider there are a total of 2,180 House candidates, of which 868 were women (about 40\%). For consistency, we only consider candidates to the House from the parties and provinces included in the sample described above.

We have gathered information on appointed senators from the Senate website. ${ }^{27}$ In 1996 through 2008, there were 142 appointed senators, of which 27 were women (about 19\%).

\section{References}

[1] Alvarez, R. Michael, Betsy Sinclair and Richard L. Hasen (2006), How Much is Enough? The "Ballot Order Effect" and the Use of Social Science Research in Election Law Disputes, Election Law Journal, Vol. 5(1), pp. 40-56.

[2] Beaman, Lori, Raghabendra Chattopadhyay, Esther Duflo, Rohini Pande and Petia Topalova (2009), Powerful Women: Does Exposure Reduce Prejudice? Quarterly Journal of Economics, forthcoming.

[3] Becker, Gary S. (1957), The Economics of Discrimination (Chicago: The University of Chicago Press)

[4] Caul, Miki (1999), Women's Representation in Parliament: The Role of Political Parties, Party Politics, Vol. 5, pp. 79-98.

[5] Chattopadhyay, Raghabendra and Esther Duflo (2004), Women as Policy Makers: Evidence from a Randomized Policy Experiment in India, Econometrica, Vol. 72(5), pp.1409-43.

[6] Darcy, R. and Sarah Slavin Schramm (1977), When Women Run Against Men, Public Opinion Quarterly, Vol. 41(1), pp. 1-12.

[7] Einav, Liran and Leeat Yariv (2006), What's in a Surname? The Effects of Surname Initials on Academic Success, Journal of Economic Perspectives, Vol. 20(1), pp. 175-88.

\footnotetext{
${ }^{26}$ Information on candidates to the House of Representatives is available from the State Gazette website (Boletin Oficial del Estado, http://www.boe.es).

${ }^{27} \mathrm{http}: / /$ www.senado.es, retrieved April 1, 2009
} 
[8] European Commission (2009), "Women in European Politics - A Time for Action", Report by the Directorate-General for Employment, Social Affairs and Equal Opportunities Unit G1

[9] Ferraz, Claudio and Federico Finan (2009), Motivating Politicians: The Impact of Monetary Incentives on Quality and Performance, NBER Working Paper No. 14906

[10] Frechette, Guillaume R., Francois Maniquet and Massimo Morelli (2008), Incumbents' Interests and Gender Quotas, American Journal of Political Science, Vol. 52(4), pp. 891-909.

[11] Frechette, Guillaume R., Francois Maniquet and Massimo Morelli (2006), Incumbents' Interests, Voters' Bias and Gender Quotas, mimeo, Columbia University

[12] Gagliarducci, Stefano and Tommaso Nannicini (2009), Do Better-Paid Politicians Perform Better? Disentangling Incentives from Selection, Università Bocconi Working Paper No. 346

[13] Galasso, Vincenzo and Tommaso Nannicini (2009), Competing on Good Politicians, CEPR Discussion Paper No. 7363

[14] Kelley, Jonathan and Ian McAllister (1984), Ballot Paper Cues and the Vote in Australia and Britain: Alphabetical Voting, Sex, and Title, Public Opinion Quarterly, Vol. 48, pp. 452-66.

[15] Koppell, Jonathan G. S. and Jennifer A. Steen (2004), The Effects of Ballot Position on Election Outcomes, Journal of Politics, Vol. 66(1), pp. 267-81.

[16] Lijphart, A. and R. Lopez (1988), Alphabetical Bias in Partisan Elections: Patterns of Voting for the Spanish Senate, 1982 and 1986, Electoral Studies

[17] Matland, Richard E. (2005), The Norwegian Experience of Gender Quotas, in "The Implementation of Quotas: European Experiences", ed. by Julie Ballington (International Idea: Sweden)

[18] Miller, Joanne M. and Jon A. Krosnick (1998), The Impact of Candidate Name Order on Election Outcomes, Public Opinion Quarterly, Vol. 62(3), pp. 291-330.

[19] Montabes Pereira, Juan and Carmen Ortega Villodres (2002), El Voto Limitado en las Elecciones al Senado Español: Estrategias de Nominación y Rendimientos Partidistas en las Elecciones de Marzo de 2000, Revista Española de Ciencia Política, Vol. 7, pp. 103-30.

[20] Murray, Rainbow (2004), Why Didn't Parity Work? A Closer Examination of the 2002 Election Results, French Politics, Vol. 2(3), pp. 347-62.

[21] Ortega Villodres, Carmen and B. Morata García de la Puerta (2004), Votantes y Candidaturas Femeninas: Un Estudio de las Elecciones al Senado de Marzo del 2000, Psicología Política, Vol. 28, pp. 69-84.

[22] Persico, Nicola (2009), Quote Rosa: Un Fallimento della Politica, LaVoce.info, September 29

[23] Rehavi, Marit (2007), Sex and Politics: Do Female Legislators Affect State Spending?, mimeo, University of Michigan

[24] Robson, Christopher and Brendan M. Walsh (1974), The Importance of Positional Voting Bias in the Irish General Election of 1973, Political Studies, Vol. 22, pp. 191-203. 
[25] Shue, Kelly and Erzo F. P. Luttmer (2009), Who Misvotes? The Effect of Differential Cognition Costs on Election Outcomes, American Economic Journal: Economic Policy, Vol. 1(1), pp. 22957.

[26] Verge, Tània (2006), Mujer y Partidos Políticos en España: las Estrategias de los Partidos y su Impacto Institucional, 1978-2004, Revista Española de Investigaciones Sociológicas, Vol. 115

[27] Verge, Tània (2009), Party Candidate Selection Processes and the Gender Regime in Spain, paper prepared for the I ECPR Conference on Politics and Gender (ECPG) in Belfast

[28] UNICEF (2007), The State of the World's Children: Women and Children: The Double Dividend of Gender Equality (New York: United Nations)

Figure 1. Female legislators (\%), Spain and OECD countries

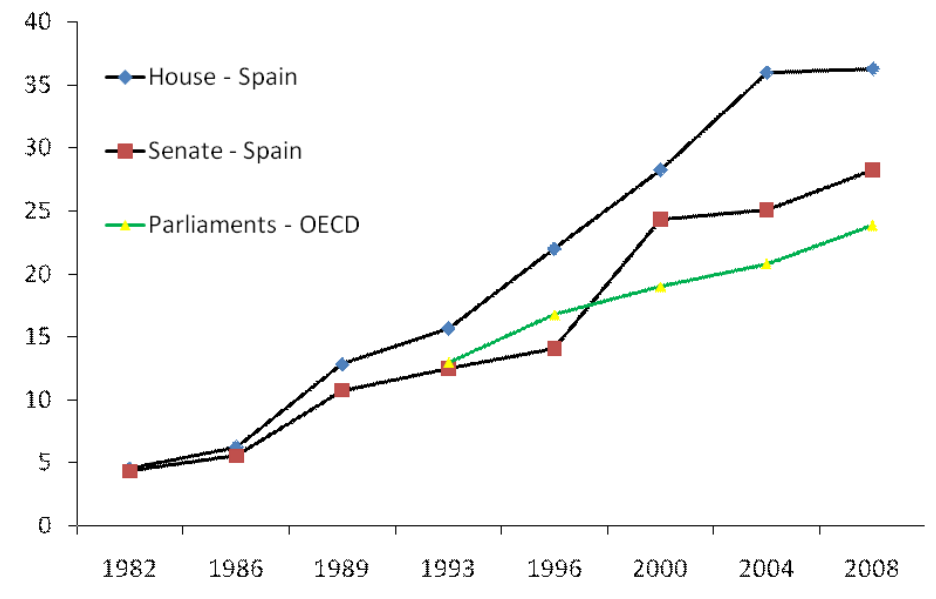

Source - Instituto de la Mujer and World Development Indicators 
Figure 2. Senate election ballot, Province of Ávila, 2008 election

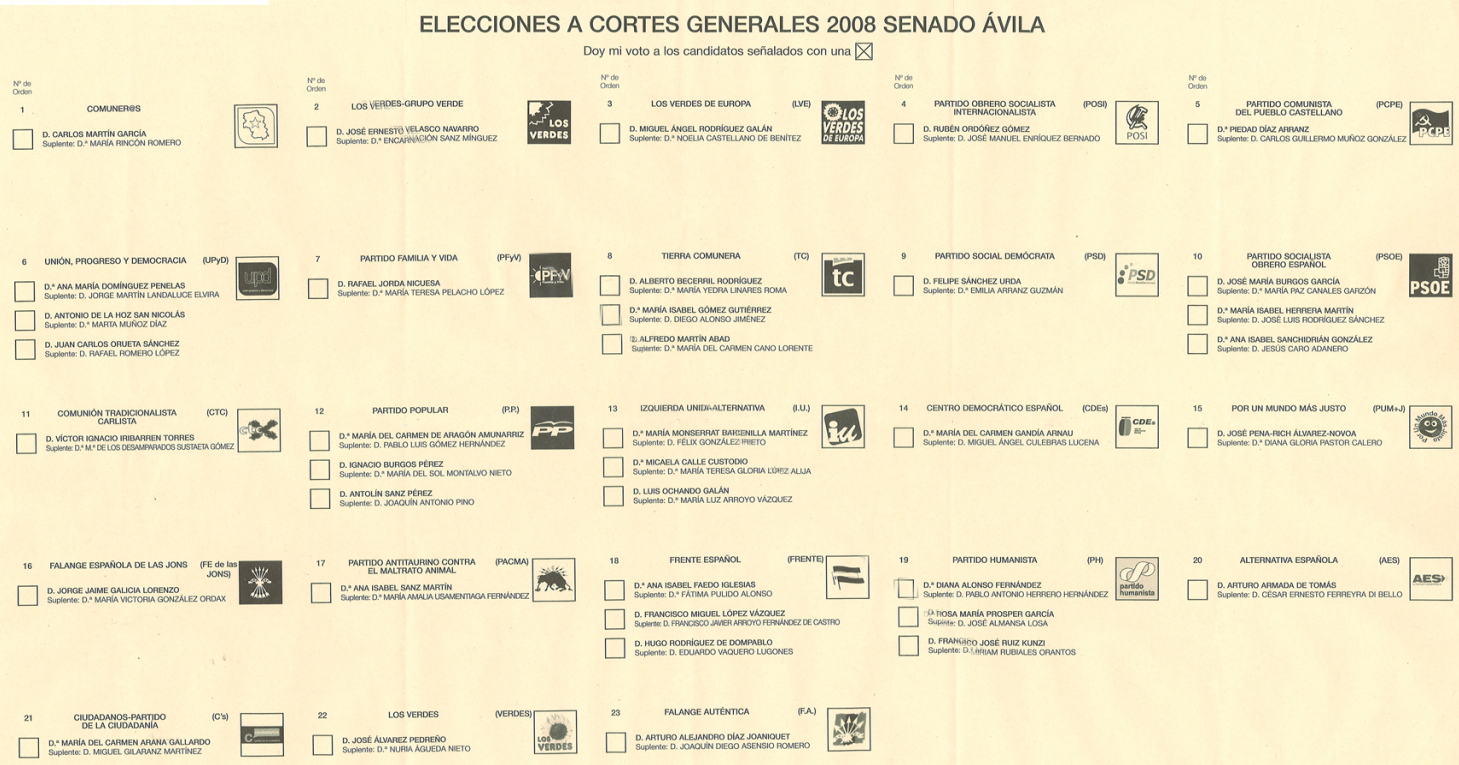

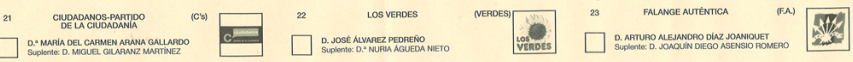

Figure 3. Senate results, Province of Ávila, 2008 election

\begin{tabular}{|l|l|l|l|}
\hline Candidate Name & Party & Votes & Elected \\
\hline 1. Aragón Amunarriz, María del Carmen & People's Party & 64,052 & Yes \\
\hline 2. Burgos Pérez, Ignacio & People's Party & 63,288 & Yes \\
\hline 3. Sanz Pérez, Antolín & People's Party & 62,743 & Yes \\
\hline 4. Burgos García, José María & Socialist Party & 39,208 & Yes \\
\hline 5. Herrera Martín, María Isabel & Socialist Party & 36,975 & No \\
\hline 6. Sanchindrián González, Ana Isabel & Socialist Party & 36,523 & No \\
\hline
\end{tabular}


Figure 4. Share of women in House lists by type of position

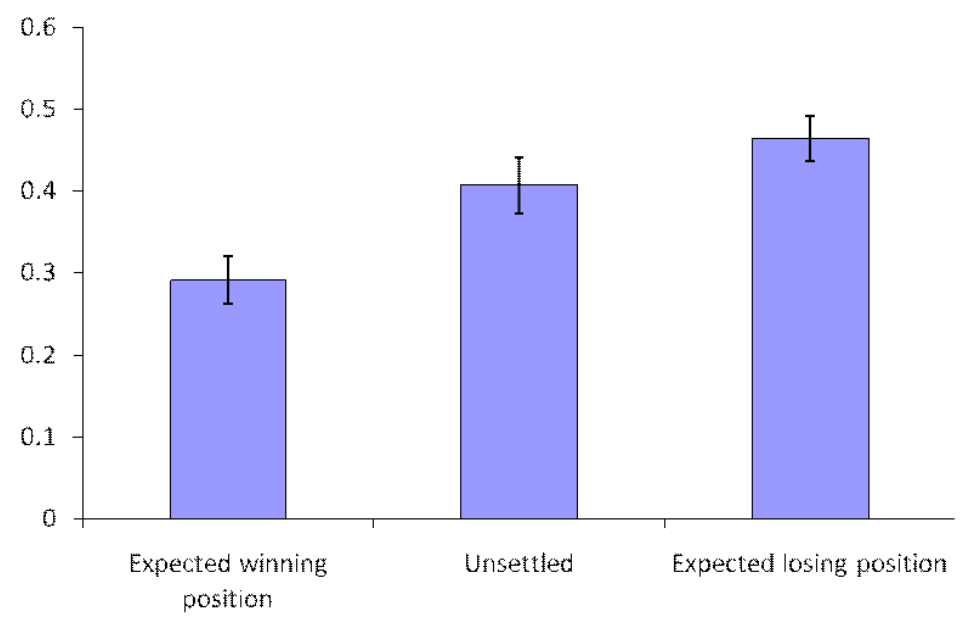

Source - Authors' calculations using data corresponding to the 1996, 2000, 2004 and 2008 House of Representatives elections. In a list where the party obtained X seats in the previous House election, the $\mathrm{X}-1$ first positions are considered expected winning positions, the $\mathrm{X}$ and $\mathrm{X}+1$ positions are considered unsettled, and the rest are considered expected losing position. Black vertical lines denote $95 \%$ confidence intervals

Figure 5. Lists obtaining three seats (\%) according to their vote advantage in the previous election (\%), Spanish Senate

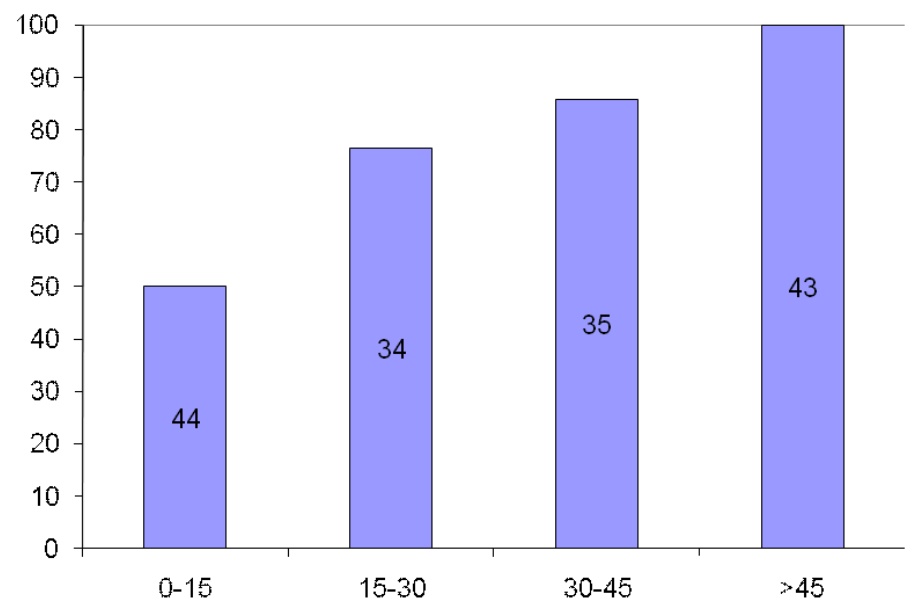

Source - Authors' calculations using data from the 1996, 2000, 2004 and 2008 elections. Vote advantage has been calculated as the difference in votes between the two parties in the previous election divided by the number of votes obtained by the second party. Size of the sample is inside the bar 
Figure 6. Maps of political party lists in Spain, 1996, 2000, 2004 and 2008 Senate elections
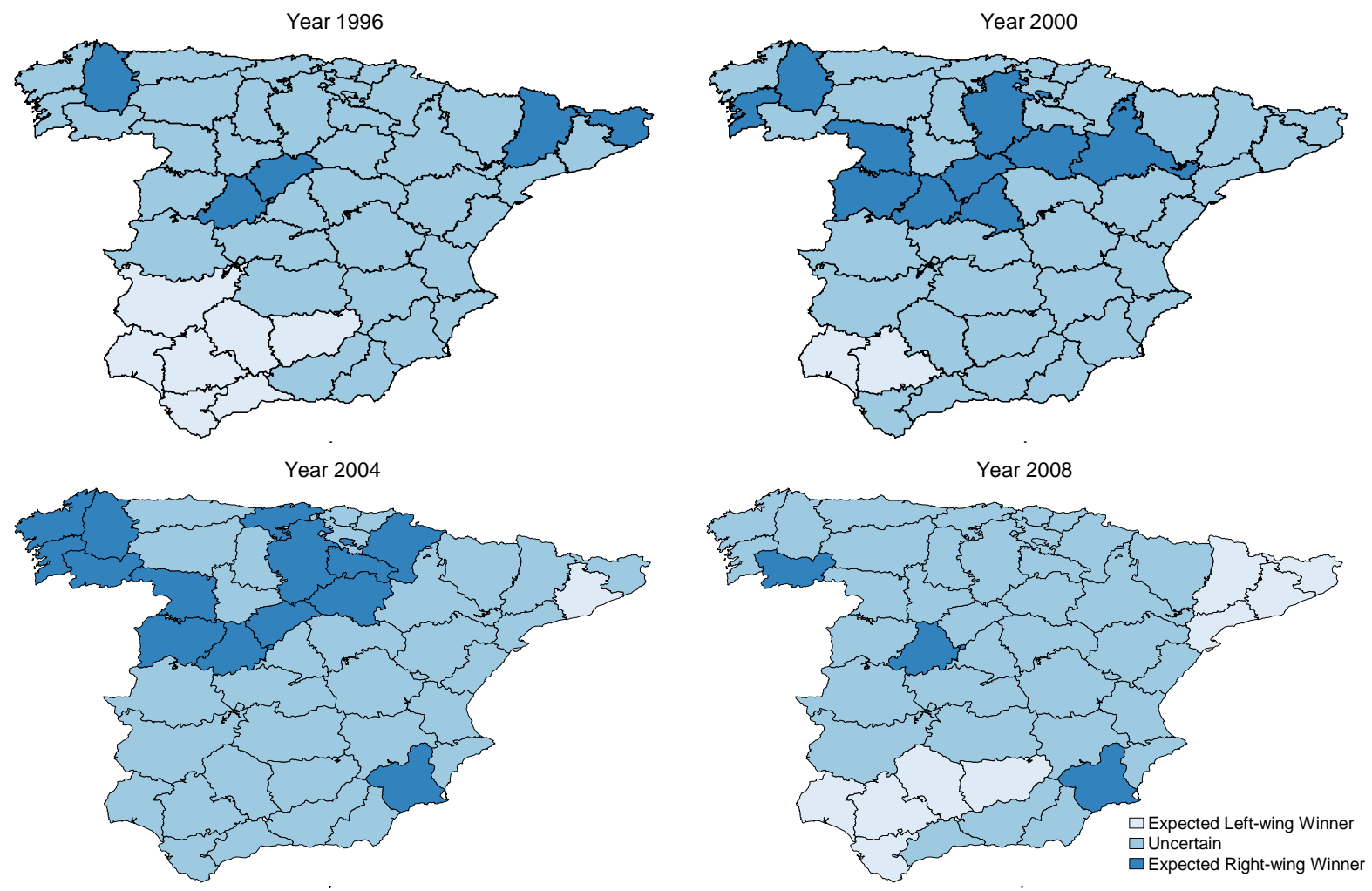

Figure 7. Share of university graduates by surname order decile and gender
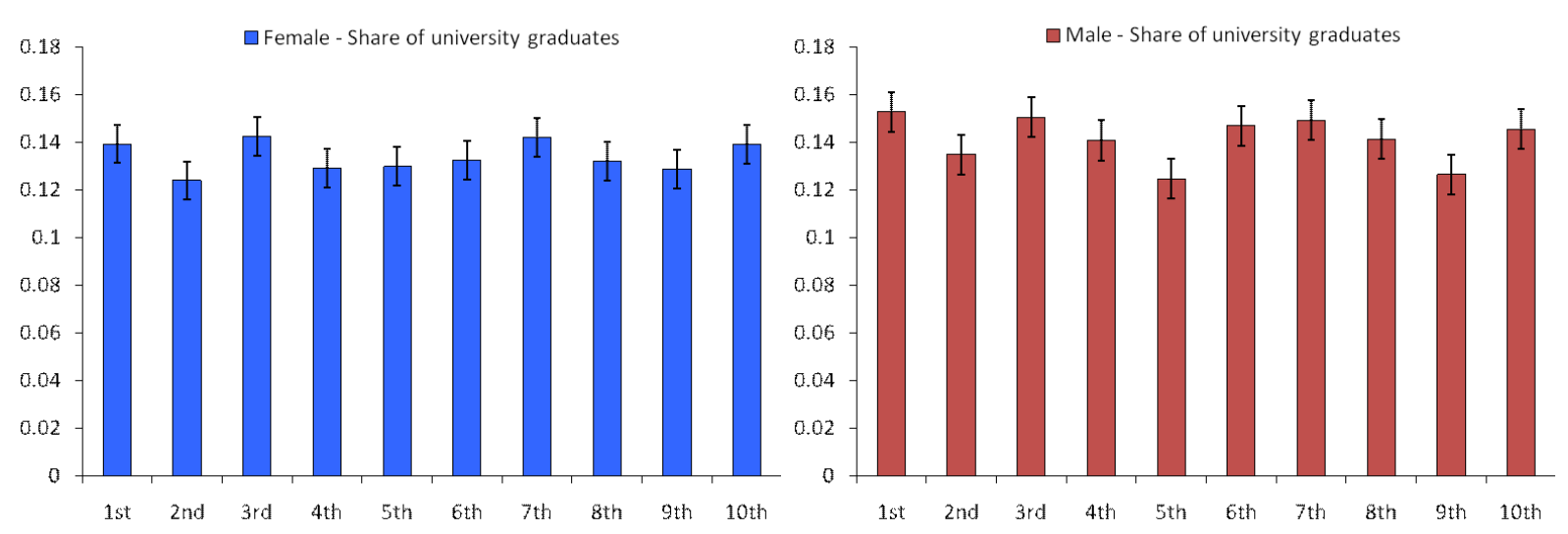

Source - Santander Census 2001 - individuals between 30 and 70 years of age with a university degree (diplomado or licenciado) by decile of surname order and gender $(\mathrm{N}=279,813)$ 
Figure 8. Surname order by type of list and gender

A. Senate candidates

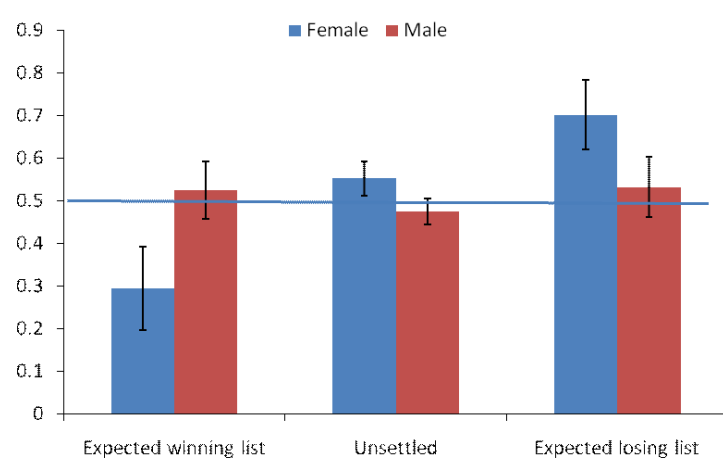

C. Mayors

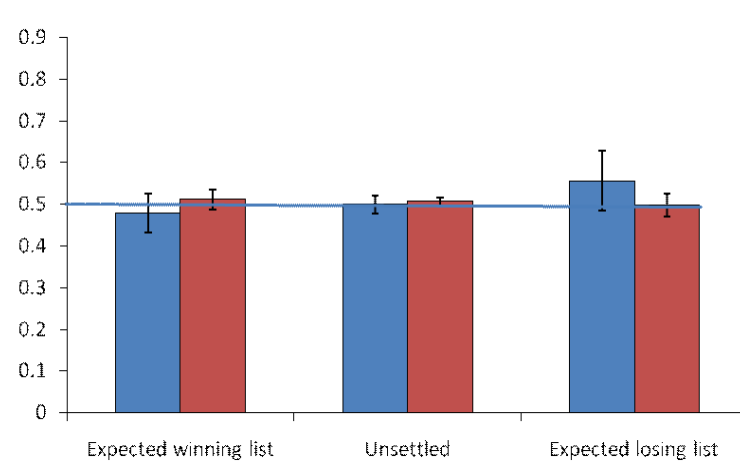

B. Senate candidates (maternal surnames)

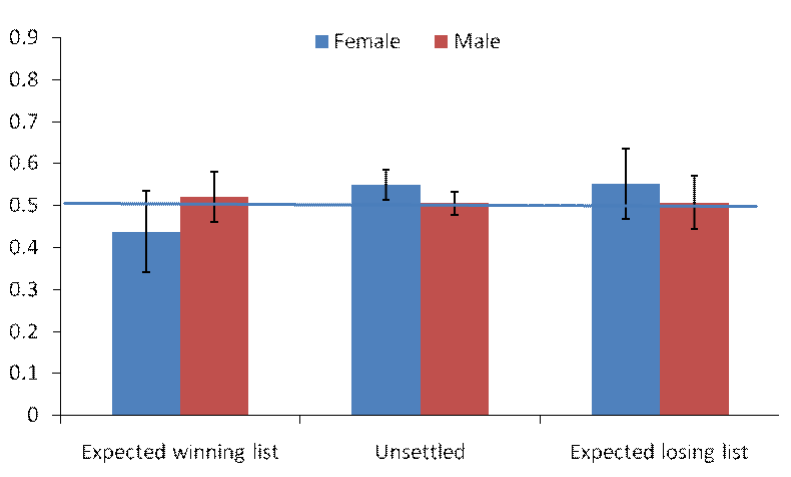

D. Candidates to local elections

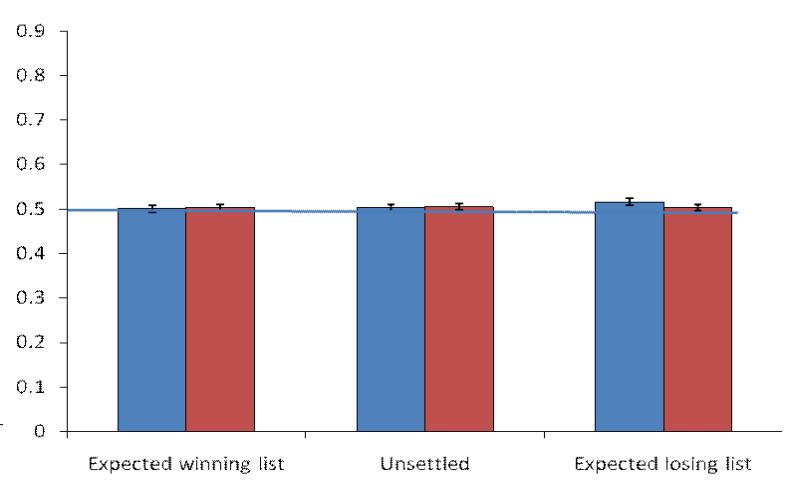

Source - Authors' calculations using data corresponding to the 1996, 2000, 2004 and 2008 national elections for figure A and B, and from the 2007 local elections for figures C and D. Figure C uses the sample of 6084 mayors, Figure D uses the sample of 96,478 local election candidates. Surname order indicates the percentile where the candidate's surname is alphabetically located within the Spanish population. Black vertical lines denote $95 \%$ confidence intervals 
Figure 9. Share of female Senate candidates by type of list and election

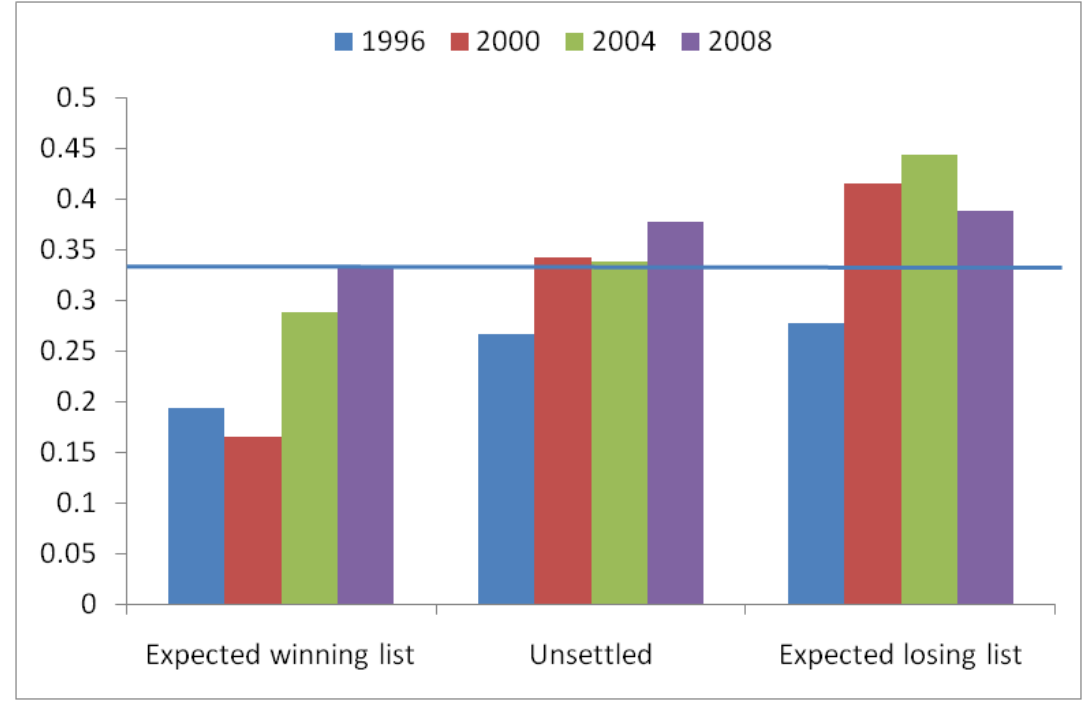

Source - Authors' calculations. The horizontal line indicates the gender quota

Figure 10. Surname order of Senate candidates by type of list and gender, 2008 election

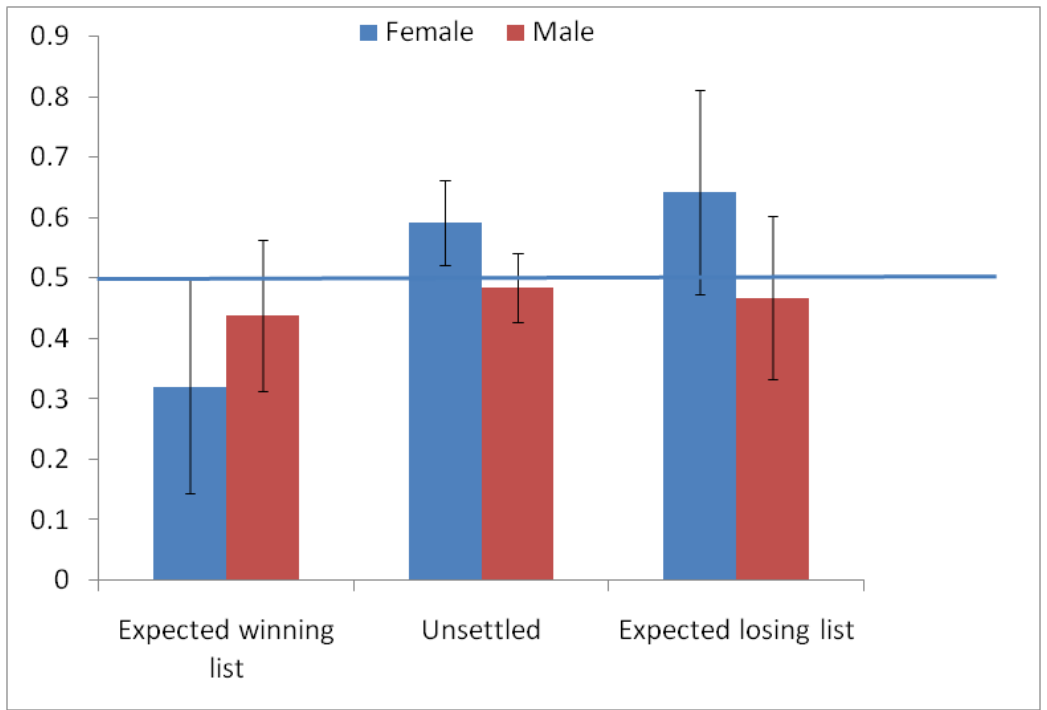

Source - Authors' calculations. Black vertical lines denote $95 \%$ confidence intervals 
Figure 11. Share of candidates in winning positions on House ballot, by gender 1996, 2000, 2004 and 2008 elections

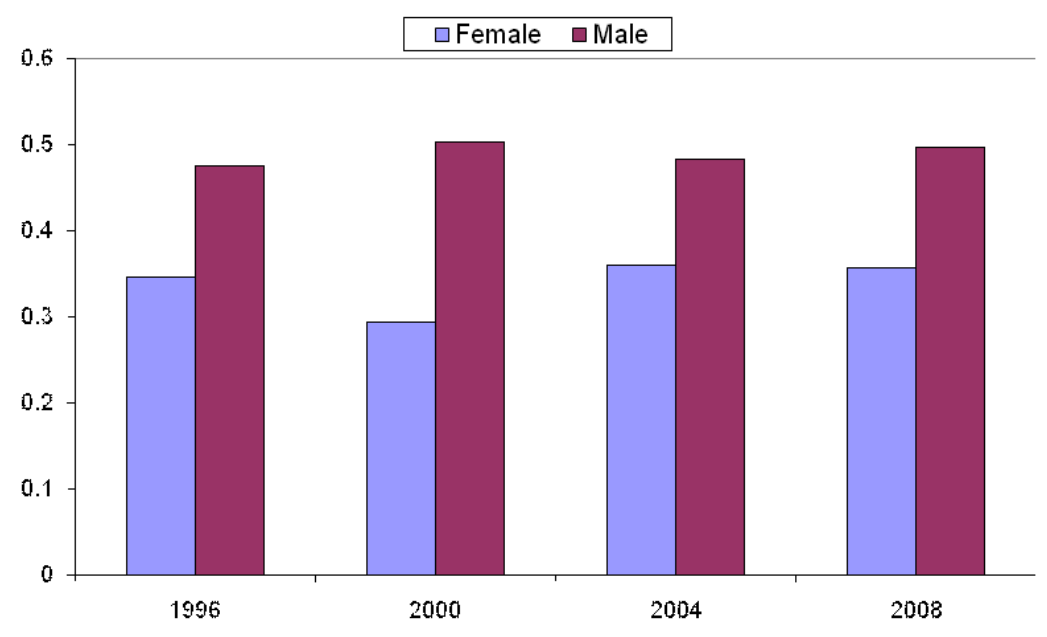

Source - Authors' calculations

Table 1: Descriptive statistics - Last name order, by gender

\begin{tabular}{|c|c|c|c|}
\hline & $\begin{array}{c}\text { Male } \\
(1)\end{array}$ & $\begin{array}{c}\text { Female } \\
(2)\end{array}$ & $\begin{array}{c}\text { p-value } \\
(3)\end{array}$ \\
\hline \multicolumn{4}{|l|}{ Senate } \\
\hline Candidates to the Senate & $\begin{array}{l}0.49 \\
{[629]}\end{array}$ & $\begin{array}{c}0.55 \\
{[307]}\end{array}$ & 0.01 \\
\hline Elected senators & $\begin{array}{l}0.43 \\
{[471]}\end{array}$ & $\begin{array}{c}0.42 \\
{[153]}\end{array}$ & 0.67 \\
\hline Appointed senators & $\begin{array}{l}0.48 \\
{[115]}\end{array}$ & $\begin{array}{l}0.42 \\
{[27]}\end{array}$ & 0.34 \\
\hline Candidates to the Senate - maternal surname & $\begin{array}{l}0.51 \\
{[629]}\end{array}$ & $\begin{array}{c}0.53 \\
{[307]}\end{array}$ & 0.22 \\
\hline Elected senators - maternal surname & $\begin{array}{l}0.50 \\
{[471]}\end{array}$ & $\begin{array}{c}0.52 \\
{[153]}\end{array}$ & 0.52 \\
\hline \multicolumn{4}{|l|}{ House of Representatives } \\
\hline Candidates to the House & $\begin{array}{c}0.48 \\
{[1311]}\end{array}$ & $\begin{array}{l}0.50 \\
{[869]}\end{array}$ & 0.28 \\
\hline Elected House members & $\begin{array}{l}0.49 \\
{[682]}\end{array}$ & $\begin{array}{l}0.51 \\
{[312]}\end{array}$ & 0.33 \\
\hline \multicolumn{4}{|l|}{ Local government } \\
\hline Candidates in local elections & $\begin{array}{c}0.50 \\
{[59838]}\end{array}$ & $\begin{array}{c}0.50 \\
{[36640]}\end{array}$ & 0.97 \\
\hline Mayors & $\begin{array}{c}0.51 \\
{[5096]}\end{array}$ & $\begin{array}{l}0.50 \\
{[988]}\end{array}$ & 0.50 \\
\hline
\end{tabular}

Notes: Columns (1) and (2) provide means, column (3) provides the p-value for the test of the null hypothesis that the difference between columns (1) and (2) is zero. The number of observations is in brackets. 
Table 2: Descriptive statistics - previous political experience of Senate candidates, by gender

\begin{tabular}{l|c|c|c}
\hline \hline & $\begin{array}{c}\text { Male } \\
(1)\end{array}$ & $\begin{array}{c}\text { Female } \\
(2)\end{array}$ & $\begin{array}{c}\text { p-value } \\
(3)\end{array}$ \\
\hline Senator & 0.42 & 0.20 & 0.00 \\
Member of the House of Representatives & 0.18 & 0.10 & 0.00 \\
Mayor, capital & 0.07 & 0.00 & 0.00 \\
Mayor, other & 0.25 & 0.15 & 0.00 \\
Town councilor, capital & 0.15 & 0.10 & 0.05 \\
Town councilor, other & 0.22 & 0.30 & 0.01 \\
First in the ballot & 0.39 & 0.21 & 0.00 \\
Votes (\%) & 41.4 & 40.1 & 0.02 \\
Number of observations & 629 & 307 & \\
\hline \hline
\end{tabular}

Notes: Columns (1) and (2) provide means, column (3) provides the p-value for the test of the null hypothesis that the difference between columns (1) and (2) is zero. 'Other' denotes a town that is not the capital of the province.

Table 3: Vote ranking according to order in the ballot

\begin{tabular}{c|c|c|c|c}
\hline \hline Ranking in Votes & First (\%) & $\begin{array}{c}\text { Second (\%) } \\
(2)\end{array}$ & $\begin{array}{c}\text { Third (\%) } \\
(3)\end{array}$ & $\begin{array}{c}\text { Total } \\
(4)\end{array}$ \\
Position in the Ballot & $(1)$ & 7 & 2 & 312 \\
\hline First in the ballot & 303 & $(2.24)$ & $(0.64)$ & $(100)$ \\
$(\%)$ & $(97.1)$ & 285 & 19 & 312 \\
Second in the ballot & 8 & $(91.35)$ & $(6.09)$ & $(100)$ \\
$(\%)$ & $(2.56)$ & 20 & 291 & 312 \\
Third in the ballot & 1 & $(6.41)$ & $(93.27)$ & $(100)$ \\
$(\%)$ & $(0.32)$ & \\
\hline \hline
\end{tabular}

Notes: The table indicates the ranking in votes obtained by candidates within a certain party list according to their position in the ballot. For instance, of all candidates who were placed first in the ballot, $97.1 \%$ ranked first in votes, $2.24 \%$ of candidates ranked second in votes, and $0.64 \%$ ranked third (that is, last) in votes. The number of observations is 936 candidacies.

Table 4: Share of women according to order in the ballot and type of list

\begin{tabular}{l|c|c|c|c}
\hline \hline $\begin{array}{r}\text { Type of list: } \\
\text { Position in the Ballot }\end{array}$ & $\begin{array}{c}\text { Expected winning } \\
(1)\end{array}$ & $\begin{array}{c}\text { Unsettled } \\
(2)\end{array}$ & $\begin{array}{c}\text { Expected losing } \\
(3)\end{array}$ & $\begin{array}{c}\text { Average } \\
(4)\end{array}$ \\
\hline First in the ballot & 47 & 19 & 7 & 21 \\
Second in the ballot & 21 & 39 & 51 & 38 \\
Third in the ballot & 12 & 42 & 56 & 39 \\
\hline Average & 26 & 33 & 38 & 33 \\
\hline \hline
\end{tabular}

Notes: The table indicates the share of women among candidates within a certain party list according to their position in the ballot. 
Table 5: Share of female candidates

\begin{tabular}{l|c|c}
\hline \multicolumn{1}{c}{ Dependent variable: } & \multicolumn{2}{|c}{ Share of women } \\
& $(1)$ & $(2)$ \\
\hline Expected winning list & $-0.12^{* * *}$ & $-0.08^{*}$ \\
& $(0.04)$ & $(0.05)$ \\
Unsettled race & -0.05 & -0.00 \\
& $(0.03)$ & $(0.03)$ \\
Party won the previous election & & -0.02 \\
& & $(0.03)$ \\
Share of females in previous election & & $0.14^{* *}$ \\
& & $(0.06)$ \\
Year and Party fixed-effects & no & yes \\
Province fixed-effects & no & yes \\
Number of observations & 312 & 312 \\
\hline \hline
\end{tabular}

Notes: Standard errors clustered at the Year*Province level in parentheses. The omitted group is expected losing lists. * significant at $10 \%$; $* *$ significant at $5 \% ; * * *$ significant at $1 \%$.

Table 6: Candidates' place on the ballot by type of list

\begin{tabular}{|c|c|c|c|c|c|c|}
\hline \multirow{3}{*}{$\begin{array}{c}\text { Dependent variable: } \\
\text { List type: }\end{array}$} & \multicolumn{6}{|c|}{ Placed on top of the ballot [Probit] } \\
\hline & \multicolumn{2}{|c|}{ Expected winner } & \multicolumn{2}{|c|}{ Unsettled } & \multicolumn{2}{|c|}{ Expected loser } \\
\hline & (1) & $(2)$ & $(3)$ & $(4)$ & $(5)$ & (6) \\
\hline Female & $\begin{array}{c}0.35^{* * *} \\
(0.11)\end{array}$ & $\begin{array}{c}0.66^{* * *} \\
(0.13)\end{array}$ & $\begin{array}{c}-0.22^{* * *} \\
(0.03)\end{array}$ & $\begin{array}{c}-0.15^{* * *} \\
(0.04)\end{array}$ & $\begin{array}{c}-0.44^{* * *} \\
(0.06)\end{array}$ & $\begin{array}{c}-0.41^{* * *} \\
(0.10)\end{array}$ \\
\hline Incumbent & & $\begin{array}{c}0.03 \\
(0.14)\end{array}$ & & $\begin{array}{c}0.30 * * * \\
(0.05)\end{array}$ & & $\begin{array}{c}0.67^{* * *} \\
(0.14)\end{array}$ \\
\hline Former House member & & $\begin{array}{c}0.22 \\
(0.19)\end{array}$ & & $\begin{array}{c}0.25^{* * *} \\
(0.06)\end{array}$ & & $\begin{array}{c}0.12 \\
(0.22)\end{array}$ \\
\hline Mayor, capital & & $\begin{array}{l}-0.03 \\
(0.27)\end{array}$ & & $\begin{array}{c}0.12 \\
(0.11)\end{array}$ & & $\begin{array}{c}0.45 \\
(0.28)\end{array}$ \\
\hline Mayor, other & & $\begin{array}{c}0.19 \\
(0.15)\end{array}$ & & $\begin{array}{c}0.03 \\
(0.06)\end{array}$ & & $\begin{array}{l}-0.11 \\
(0.14)\end{array}$ \\
\hline Town councilor, capital & & $\begin{array}{l}-0.20 \\
(0.13)\end{array}$ & & $\begin{array}{c}0.11 \\
(0.07)\end{array}$ & & $\begin{array}{c}0.06 \\
(0.28)\end{array}$ \\
\hline Town councilor, other & & $\begin{array}{c}-0.41^{* *} \\
(0.05)\end{array}$ & & $\begin{array}{l}-0.05 \\
(0.05)\end{array}$ & & $\begin{array}{l}-0.19 \\
(0.14)\end{array}$ \\
\hline Year and Party fixed-effects & no & yes & no & yes & no & yes \\
\hline Province fixed-effects & no & yes & no & yes & no & yes \\
\hline Number of observations & 129 & 129 & 678 & 678 & 129 & 129 \\
\hline
\end{tabular}

Notes: Standard errors clustered at the Year*Province level in parentheses.

*significant at $10 \%$;* significant at $5 \%$; *** significant at $1 \%$. 
Table 7: Female at the top of the Senate and House ballots, by type of list

\begin{tabular}{l|c|c|c}
\hline \hline & \multicolumn{3}{|c}{ Cases (\%) } \\
\hline List type: & $\begin{array}{c}\text { Expected winner } \\
(1)\end{array}$ & $\begin{array}{c}\text { Unsettled } \\
(2)\end{array}$ & $\begin{array}{c}\text { Expected loser } \\
(3)\end{array}$ \\
\hline Top of the list in Senate is female & 20 & 42 & 3 \\
$(\%)$ & $(46.51)$ & $(18.58)$ & $(6.98)$ \\
Top of the list in House is female & 10 & 42 & 13 \\
$(\%)$ & $(23.26)$ & $(18.58)$ & $(30.23)$ \\
Number of observations & 43 & 226 & 43 \\
\hline \hline
\end{tabular}

Table 8: Female at the top of the Senate and House ballots

\begin{tabular}{l|c|c}
\hline \hline \multicolumn{1}{c|}{ Dependent variable: } & Female at the top of House list [Probit] \\
& $(1)$ & $(2)$ \\
\hline Female at the top of Senate list & $-0.10^{*}$ & $-0.32^{* *}$ \\
Vote advantage in previous election & $(0.05)$ & $(0.13)$ \\
& -0.04 & 0.14 \\
Incumbent & $(0.07)$ & $(0.22)$ \\
& -0.07 & -0.18 \\
Share of female in the House list & $(0.05)$ & $(0.12)$ \\
& $0.49^{* *}$ & $1.04^{*}$ \\
Won last election & $(0.20)$ & $(0.57)$ \\
& 0.06 & 0.22 \\
Year fixed-effects & $(0.07)$ & $(0.22)$ \\
Party*Province fixed-effects & yes & yes \\
Number of observations & no & yes \\
\hline \hline
\end{tabular}

Notes: Standard errors clustered at the Year*Province level in parentheses.

The sample in column (2) is smaller than the sample in column (1) due to the lack of variability in the gender of the head list in a give province and party over time. *significant at $10 \%$; **significant at $5 \%$; ***significant at $1 \%$. 
Table 9: Candidates' last name order by type of list

\begin{tabular}{|c|c|c|c|c|c|c|}
\hline \multirow{3}{*}{$\begin{array}{c}\text { Dependent variable: } \\
\text { List type: }\end{array}$} & \multicolumn{6}{|c|}{ Surname order } \\
\hline & \multicolumn{2}{|c|}{ Expected winner } & \multicolumn{2}{|c|}{ Unsettled } & \multicolumn{2}{|c|}{ Expected loser } \\
\hline & (1) & $(2)$ & (3) & $(4)$ & (5) & (6) \\
\hline Female & $\begin{array}{c}-0.23^{* * *} \\
(0.05)\end{array}$ & $\begin{array}{c}-0.27^{* * *} \\
(0.04)\end{array}$ & $\begin{array}{c}0.08^{* * *} \\
(0.02)\end{array}$ & $\begin{array}{c}0.03 \\
(0.02)\end{array}$ & $\begin{array}{c}0.17^{* * *} \\
(0.05)\end{array}$ & $\begin{array}{l}0.15^{* *} \\
(0.06)\end{array}$ \\
\hline Incumbent & & $\begin{array}{c}0.04 \\
(0.07)\end{array}$ & & $\begin{array}{c}-0.14^{* * *} \\
(0.02)\end{array}$ & & $\begin{array}{c}-0.19^{* * *} \\
(0.06)\end{array}$ \\
\hline Former House member & & $\begin{array}{l}-0.07 \\
(0.08)\end{array}$ & & $\begin{array}{l}-0.06 \\
(0.04)\end{array}$ & & $\begin{array}{l}-0.07 \\
(0.06)\end{array}$ \\
\hline Mayor, capital & & $\begin{array}{c}0.25 \\
(0.27)\end{array}$ & & $\begin{array}{l}-0.09 \\
(0.06)\end{array}$ & & $\begin{array}{c}0.20^{* *} \\
(0.09)\end{array}$ \\
\hline Mayor, other & & $\begin{array}{l}-0.11 \\
(0.07)\end{array}$ & & $\begin{array}{l}-0.02 \\
(0.03)\end{array}$ & & $\begin{array}{c}0.09 \\
(0.08)\end{array}$ \\
\hline Town councilor, capital & & $\begin{array}{c}0.09 \\
(0.11)\end{array}$ & & $\begin{array}{c}-0.10^{* *} \\
(0.04)\end{array}$ & & $\begin{array}{l}-0.04 \\
(0.10)\end{array}$ \\
\hline Town councilor, other & & $\begin{array}{l}0.19^{*} \\
(0.10)\end{array}$ & & $\begin{array}{l}-0.01 \\
(0.03)\end{array}$ & & $\begin{array}{c}0.11 \\
(0.08)\end{array}$ \\
\hline Year and Party fixed-effects & no & yes & no & yes & no & yes \\
\hline Province fixed-effects & no & yes & no & yes & no & yes \\
\hline Number of observations & 129 & 129 & 678 & 678 & 129 & 129 \\
\hline
\end{tabular}

Notes: Standard errors clustered at the Year*Province level in parentheses.

*significant at $10 \% ;{ }^{* *}$ significant at $5 \%$; ***significant at $1 \%$.

Table 10: Votes by type of list

\begin{tabular}{|c|c|c|c|c|c|c|c|c|c|c|c|c|}
\hline \multirow{3}{*}{$\begin{array}{c}\text { Dependent } \\
\text { variable: }\end{array}$} & \multicolumn{12}{|c|}{ Votes $(\%)$} \\
\hline & \multicolumn{3}{|c|}{ All lists } & \multicolumn{3}{|c|}{ Expected winning lists } & \multicolumn{3}{|c|}{ Unsettled races } & \multicolumn{3}{|c|}{ Expected losing lists } \\
\hline & (1) & $(2)$ & (3) & (4) & (5) & (6) & (7) & (8) & (9) & $(10)$ & (11) & $(12)$ \\
\hline Female & $\begin{array}{l}-0.09 \\
(0.17)\end{array}$ & $\begin{array}{c}0.16^{* *} \\
(0.08)\end{array}$ & $\begin{array}{c}0.21^{* * *} \\
(0.07)\end{array}$ & $\begin{array}{l}1.26^{* *} \\
(0.47)\end{array}$ & $\begin{array}{l}0.30^{*} \\
(0.17)\end{array}$ & $\begin{array}{c}0.33^{* *} \\
(0.15)\end{array}$ & $\begin{array}{c}-0.32^{* *} \\
(0.13)\end{array}$ & $\begin{array}{c}0.08 \\
(0.07)\end{array}$ & $\begin{array}{c}0.14^{* *} \\
(0.07)\end{array}$ & $\begin{array}{l}-0.64 \\
(0.40)\end{array}$ & $\begin{array}{c}0.12 \\
(0.11)\end{array}$ & $\begin{array}{c}0.19 \\
(0.12)\end{array}$ \\
\hline First & & $\begin{array}{c}1.68^{* * *} \\
(0.10)\end{array}$ & $\begin{array}{c}1.62^{* * *} \\
(0.09)\end{array}$ & & $\begin{array}{c}1.98^{* * *} \\
(0.21)\end{array}$ & $\begin{array}{c}1.89 * * * \\
(0.17)\end{array}$ & & $\begin{array}{c}1.55^{* * *} \\
(0.08)\end{array}$ & $\begin{array}{c}1.49^{* * *} \\
(0.07)\end{array}$ & & $\begin{array}{c}1.82^{* * *} \\
(0.20)\end{array}$ & $\begin{array}{c}1.73^{* * * *} \\
(0.12)\end{array}$ \\
\hline Second & & $\begin{array}{c}0.46^{* * *} \\
(0.04)\end{array}$ & $\begin{array}{c}0.45^{* * *} \\
(0.04)\end{array}$ & & $\begin{array}{c}0.62^{* * *} \\
(0.14)\end{array}$ & $\begin{array}{c}0.55^{* * *} \\
(0.11)\end{array}$ & & $\begin{array}{c}0.40^{* * *} \\
(0.03)\end{array}$ & $\begin{array}{c}0.39 * * * \\
(0.03)\end{array}$ & & $\begin{array}{c}0.54 * * * \\
(0.11)\end{array}$ & $\begin{array}{c}0.51^{* * *} \\
(0.11)\end{array}$ \\
\hline Incumbent & & & $\begin{array}{c}0.04 \\
(0.08)\end{array}$ & & & $\begin{array}{l}-0.14 \\
(0.12)\end{array}$ & & & $\begin{array}{l}0.13^{*} \\
(0.07)\end{array}$ & & & $\begin{array}{l}-0.04 \\
(0.22)\end{array}$ \\
\hline House & & & $\begin{array}{l}0.16^{*} \\
(0.08)\end{array}$ & & & $\begin{array}{c}0.22 \\
(0.23)\end{array}$ & & & $\begin{array}{c}0.11 \\
(0.08)\end{array}$ & & & $\begin{array}{c}0.32 \\
(0.23)\end{array}$ \\
\hline Mayor, cap. & & & $\begin{array}{c}0.37^{* *} \\
(0.15)\end{array}$ & & & $\begin{array}{c}0.24 \\
(0.31)\end{array}$ & & & $\begin{array}{l}0.33^{* *} \\
(0.15)\end{array}$ & & & $\begin{array}{c}0.99 \\
(0.86)\end{array}$ \\
\hline Mayor, other & & & $\begin{array}{c}0.24^{* *} \\
(0.10)\end{array}$ & & & $\begin{array}{c}0.34 \\
(0.21)\end{array}$ & & & $\begin{array}{c}0.18^{* *} \\
(0.08)\end{array}$ & & & $\begin{array}{c}0.26 \\
(0.19)\end{array}$ \\
\hline Councilor, cap. & & & $\begin{array}{c}0.02 \\
(0.07)\end{array}$ & & & $\begin{array}{c}0.17 \\
(0.22)\end{array}$ & & & $\begin{array}{c}0.01 \\
(0.08)\end{array}$ & & & $\begin{array}{c}0.06 \\
(0.22)\end{array}$ \\
\hline Councilor, other & & & $\begin{array}{c}0.03 \\
(0.06)\end{array}$ & & & $\begin{array}{c}0.16 \\
(0.15)\end{array}$ & & & $\begin{array}{c}0.04 \\
(0.08)\end{array}$ & & & $\begin{array}{c}0.01 \\
(0.13)\end{array}$ \\
\hline $\mathrm{N}$ & 936 & 936 & 936 & 129 & 129 & 129 & 678 & 678 & 678 & 129 & 129 & 129 \\
\hline
\end{tabular}

Notes: Standard errors clustered at the Year*Province level in parentheses. All regressions include list fixed-effects. In columns (1) to (3) the list is represented by Year*Province*Party. In columns (4)-(12), lists are represented by Province*Party. Regressions are weighted by the votes received by the candidate. *significant at $10 \%$; ** significant at $5 \%$; ***ignificant at $1 \%$. 
Table 11: Votes by election year

\begin{tabular}{|c|c|c|c|c|}
\hline \multirow[t]{2}{*}{ Dependent variable: } & \multicolumn{4}{|c|}{ Votes $(\%)$} \\
\hline & 1996 & 2000 & 2004 & 2008 \\
\hline & $(1)$ & $(2)$ & (3) & $(4)$ \\
\hline Female & $\begin{array}{l}-0.09 \\
(0.15)\end{array}$ & $\begin{array}{c}0.08 \\
(0.11)\end{array}$ & $\begin{array}{c}0.21^{* * * *} \\
(0.07)\end{array}$ & $\begin{array}{c}0.37^{\text {*** }} \\
(0.09)\end{array}$ \\
\hline Order on the ballot controls & yes & yes & yes & yes \\
\hline Prior political experience & yes & yes & yes & yes \\
\hline Number of observations & 270 & 126 & 270 & 270 \\
\hline
\end{tabular}

Notes: the list is represented by Province*Party. Regressions are weighted by the votes received by the candidate.

*significant at $10 \% ;{ }^{* *}$ significant at $5 \% ;{ }^{* * *}$ significant at $1 \%$.

Table 12: Number of female senators

\begin{tabular}{l|c|c}
\hline \hline Dependent variable: & \multicolumn{2}{|c}{ Number of female senators } \\
& $(1)$ & $(2)$ \\
\hline Unsettled race & $0.06^{* *}$ & $0.06^{*}$ \\
Election year 2000 & $(0.03)$ & $(0.03)$ \\
& $0.10^{* *}$ & $0.09^{* *}$ \\
Election year 2004 & $(0.04)$ & $(0.04)$ \\
& $0.12^{* * *}$ & $0.11^{* * *}$ \\
Election year 2008 & $(0.03)$ & $(0.03)$ \\
& $0.17^{* * *}$ & $0.16^{* * *}$ \\
Left-wing victory & $(0.03)$ & $(0.03)$ \\
& $0.09^{* * *}$ & $0.13^{* * *}$ \\
Draw & $(0.02)$ & $(0.05)$ \\
Constant & -0.02 & 0.03 \\
& $(0.09)$ & $(0.10)$ \\
Province fixed-effects & $0.08^{* *}$ & $0.06^{*}$ \\
Number of observations & $(0.03)$ & $(0.04)$ \\
\hline \hline
\end{tabular}

Notes: Standard errors in parentheses. The omitted groups are settled race, election year 1996 and right-wing victory.

*significant at $10 \%$; **significant at $5 \%$; *** significant

at $1 \%$. 
Table 13: Candidates to the House of Representatives and to the Senate: last name order by type of $\underline{\underline{\text { list }}}$

\begin{tabular}{|c|c|c|c|c|c|c|c|c|c|}
\hline \multirow[b]{3}{*}{ List type: } & \multicolumn{9}{|c|}{ Dependent variable: Surname order } \\
\hline & \multicolumn{3}{|c|}{ Appointed senators } & \multicolumn{3}{|c|}{ House of Representatives candidates } & \multicolumn{3}{|c|}{ All } \\
\hline & $\begin{array}{c}\text { Expected } \\
\text { winner } \\
(1)\end{array}$ & $\begin{array}{c}\text { Unsettled } \\
(2)\end{array}$ & $\begin{array}{c}\text { Expected } \\
\text { loser } \\
(3)\end{array}$ & $\begin{array}{c}\text { Expected } \\
\text { winner } \\
(4)\end{array}$ & $\begin{array}{c}\text { Unsettled } \\
\text { (5) }\end{array}$ & $\begin{array}{c}\text { Expected } \\
\text { loser } \\
(6)\end{array}$ & $\begin{array}{c}\text { Expected } \\
\text { winner } \\
(7)\end{array}$ & $\begin{array}{c}\text { Unsettled } \\
\text { (8) }\end{array}$ & $\begin{array}{c}\text { Expected } \\
\text { loser } \\
(9)\end{array}$ \\
\hline Female & $\begin{array}{c}0.01 \\
(0.15)\end{array}$ & $\begin{array}{c}-0.09 * \\
(0.05)\end{array}$ & $\begin{array}{l}-0.02 \\
(0.09)\end{array}$ & $\begin{array}{c}0.02 \\
(0.02)\end{array}$ & $\begin{array}{c}0.03 \\
(0.02)\end{array}$ & $\begin{array}{c}-0.06^{*} \\
(0.03)\end{array}$ & $\begin{array}{c}-0.05^{* *} \\
(0.02)\end{array}$ & $\begin{array}{c}0.04^{* * *} \\
(0.01)\end{array}$ & $\begin{array}{c}0.02 \\
(0.03)\end{array}$ \\
\hline Constant & $\begin{array}{c}0.53^{* * *} \\
(0.06)\end{array}$ & $\begin{array}{c}0.47^{* * *} \\
(0.03)\end{array}$ & $\begin{array}{c}0.50^{* * *} \\
(0.08)\end{array}$ & $\begin{array}{c}0.46^{* * *} \\
(0.01)\end{array}$ & $\begin{array}{c}0.47^{* * *} \\
(0.01)\end{array}$ & $\begin{array}{c}0.51^{* * *} \\
(0.02)\end{array}$ & $\begin{array}{c}0.50 * * * \\
(0.02)\end{array}$ & $\begin{array}{c}0.48^{* * * *} \\
(0.01)\end{array}$ & $\begin{array}{c}0.53^{* * *} \\
(0.02)\end{array}$ \\
\hline $\mathrm{N}$ & 24 & 103 & 15 & 305 & 1570 & 305 & 458 & 2351 & 449 \\
\hline
\end{tabular}

Notes: Standard errors clustered at the Year*Province level in parentheses. Columns (7)-(9) include all senators (elected and appointed) as well as House candidates. ${ }^{*}$ significant at $10 \% ;{ }^{* *}$ significant at $5 \% ; * * *$ significant at $1 \%$. 


\section{ÚLTIMOS DOCUMENTOS DE TRABAJO}

2009-30: "Are Women Pawns in the Political Game? Evidence from Elect ions to the Spanish Senate, Berta Esteve-Volart y Manuel Bagues.

2009-29: “An Integrated Approach to Simulate the Impacts of Carbon Emissions Trading Schemes", Xavier Labandeira, Pedro Linares y Miguel Rodríguez.

2009-28: "Disability, Cap acity fo $r$ Work and th e Business Cycle: An In ternational Persp ective", HugoBenítez-Silva, Richard Disney y Sergi Jiménez-Martín.

2009-27: "Infant mortality, in come and adult stature in Spain", Mariano Bosch, Carlos Bozzoli y Climent Quintana-Domeque.

2009-26: "Im migration and Social Security in Spain”, Clara I. Gonzalez, J. IgnacioConde-Ruiz y Michele Boldrin.

2009-25: "Business Cycle Effect s on Labour Force Transitions for Older People in Spain", Sergi JiménezMartín y Judit Vall Castello.

2009-24: “Inequality of Opportunity and Growth”, Gustavo A. Marrero y Juan G. Rodríguez.

2009-23: "A Characterization Of The Judicial System In Spain: An alysis With Formalism Indices", Juan S. Mora.

2009-22: "Anthropometry and S ocioeconomics in the Couple: Evidence fro m the PSID", Sonia Oreffice y Climent Quintana-Domeque.

2009-21: “Stimulating Gradu ates' Re search-Oriented Caree rs: Does Aca demic Research Matt er?”, Mauro Sylos Labini y Natalia Zinovyeva.

2009-20: "Papers or Pa tents: C hannels of University Effect on Regional I nnovation", Robin Cowan y Natalia Zinovyeva.

2009-19: "Innovation, Tangible and Intangible Investments and the Value of Spanish Firms", Aitor Lacuesta, Omar Licandro, Teresa Molina y Luis A. Puch.

2009-18: "Estimation of Elasticity Price of Electricity with In complete In formation", Xavier Labandeira, José M. Labeaga y Xiral López-Otero.

2009-17: "MEDEA: A DSGE M odel for th e Span ish Economy", Pablo Burriel, Jesús FernándezVillaverde y Juan F. Rubio-Ramírez.

2009-16: "Greenhouse gases em issions, growth a nd the e nergy mix i n Eu rope: A dy namic pan el dat a approach", Gustavo A. Marrero.

2009-15: "Impact of $\mathrm{t}$ he R ise in im migrant u nemployment on public fi nances", Pablo Vazquez, Mario Alloza, Raquel Vegas y Stefano Bertozzi.

2009-14: "Responding to Financial Pressures. The Effect of Managed Care on Hospitals' Provision of Charity Care", Núria Mas.

2009-13: “Domestic Transp ort C ost R eductions a nd Fi rms' Expo rt B ehaviour", Pedro Albarran, Raquel Carrasco y Adelheid Holl.

2009-12: "Com patibility with Firm Dominance", María Fernanda Viecens.

2009-11: "Pricing Strategies in Two-Si ded Platforms: The Role of Sellers' Competition”, María Fernanda Viecens.

2009-10: "Scheduled Service Versus Personal Transportation: the Role of Distan ce", Volodymyr Bilotkach, Xavier Fageda y Ricardo Flores-Fillol.

2009-09: "Social Preferences and Strategic Uncertainty: An Experiment on Markets and Contracts", Antonio Cabrales, Rafaele Miniaci, Marco Piovesan y Giovanni Ponti.

2009-08: "Hidden Information, Bargaining Power and Efficiency: An Experiment", Antonio Cabrales, Gary Charness y Marie Claire Villeval.

2009-07: "Democracy and the curse of natural resources", Antonio Cabrales y Esther Hauk.

2009-06: "Social I nteractions a nd S pillovers: In centives,Segregation and Topo logy", Antonio Cabrales, Antoni Calvó-Armengol e Yves Zenou.

2009-05: "Chance Constrained Programming with one Discrete Random Variable in Each Constraint",Emilio Cerdá Tena y Julio Moreno Lorente.

2009-04: "Economic Value of Weather Forecasti ng Systems Inform ation: A Ri sk Ave rsion Approach", Emilio Cerdá Tena y Sonia Quiroga Gómez.

2009-03: "Population Ageing, Inequality an d th e Political Eco nomy o f Pub lic Edu cation", Francisco Martínez-Mora.

2009-02: "Real Wages over the Business Cycle: OECD Evidence from the Time and Frequency Domains", Julian Messina, Chiara Strozzi y Jarkko Turunen.

2009-01: “The Determinants Of Misrep orting Weight And Hei ght: The Role Of Social Norms", Joan Gil y Toni Mora. 